\title{
Recent Advances on the Application of Layered Double Hydroxides in Concrete-A Review
}

\author{
Zahid M. Mir ${ }^{1, *(\mathbb{D})}$, Alexandre Bastos ${ }^{2}{ }^{-}$, Daniel Höche ${ }^{1}$ and Mikhail L. Zheludkevich ${ }^{1}$ \\ 1 Institute of Materials Research, Helmholtz-Zentrum Geesthacht Centre for Materials and Coastal Research, \\ Max-Planck Str. 1, 21502 Geesthacht, Schleswig Holstein, Germany; daniel.hoeche@hzg.de (D.H.); \\ mikhail.zheludkevich@hzg.de (M.L.Z.) \\ 2 DEMaC - Department of Materials and Ceramic Engineering, and CICECO_Aveiro Institute of Materials, \\ Universidade de Aveiro, 3810-193 Aveiro, Portugal; acbastos@ua.pt \\ * Correspondence: zahid.mir@hzg.de
}

Received: 6 February 2020; Accepted: 16 March 2020; Published: 20 March 2020

check for updates

\begin{abstract}
The issue of chloride induced corrosion of reinforced concrete is a serious problem affecting infrastructure globally and causing huge economic losses. As such this issue has gained a considerable attention in the scientific community in the recent past. Layered Double Hydroxides (LDHs) have recently emerged as a new class of concrete-additives with a potential to increase the chloride resistance of concrete and mitigate corrosion. LDHs are clay like structures consisting of positively charged layers of cations with associated hydroxides and exchangeable anions in between the layers. Due to this charge balanced structure, LDHs possess the property of encapsulating an anion from the environment and replacing it with an exchangeable anion present in its layers. Potential applications include chloride entrapment in concrete and delivery of corrosion inhibiting anions. However, many versatile compositions of LDHs can be easily synthesized and their application as cement additives reach far beyond corrosion mitigation in concrete. This review presents a summary of recent advances on the applications of LDH in concrete. An extensive set of recently published literature has been critically reviewed and trends have been identified.
\end{abstract}

Keywords: layered double hydroxides; reinforcement; ion exchange; corrosion; concrete

\section{Introduction}

Our planet has experienced an unprecedented population growth in the last century [1]. The rise of population has been accompanied by an increase in building infrastructure [2], mostly concrete and steel. As a consequence, the cement production industry has significantly added to global warming with a contribution of almost $5 \%$ to the global $\mathrm{CO}_{2}$ emissions [3]. The carbon footprint of concrete industry is getting bigger as emerging economies in Asian and South-Asian regions are focusing on a rapid expansion of infrastructure. Furthermore, obsolete or outdated production facilities/methods have also contributed to an increased environmental impact of cement production [4-6]. To reduce the environmental impact of cement production, it is desirable to have concrete infrastructure with longer service life. However, due to the various degradation phenomena associated with reinforced concrete structures such as steel corrosion [7-14], freeze thaw cycles [15,16], ice abrasion [17-19], acid attack $[20,21]$ etc., the service life of infrastructure is considerably reduced.

Out of the above mentioned degradation mechanisms, reinforced concrete structures are particularly susceptible to chloride induced corrosion [7,22]. Chloride induced corrosion occurs in bridge decks, parking decks and pavements exposed to de-icing salts as well as in infrastructure exposed to marine and coastal environments such as offshore bridge piers etc. The rapid deterioration of such vital infrastructure can have severe economic, environmental and social implications 
worldwide [23]. The need of the hour is to steer concrete research towards applications of innovative low-cost materials that can increase the chloride resistance of concrete structures.

In recent times, layered double hydroxides (LDHs) have emerged as a new class of engineering materials $[24,25]$ which can aid in the corrosion control of concrete structures and potentially prolong their service life. LDHs are clay-like powdered materials which are often referred to as nano-containers or nano-reservoirs and have the ability of entrapping ions from the environment e.g., $\mathrm{Cl}^{-}$ions. Potential applications include chloride ion and carbonate ion entrapment in concrete. This work provides an overview on the state-of-the-art on the applications of LDHs in concrete technology, based on a critical review of recently published reports and articles. One of the first reviews on application of LDHs in concrete was provided by Raki et al. [26] in 2004 and Yang et al. [27,28] in 2013. Since then many research groups and companies around the globe have started to work extensively with LDHs. Therefore a lot of applications of LDH can be found across various branches of concrete technology. The authors have attempted to review cited literature up to the end of year 2019. The paper presents an understanding of corrosion processes in concrete, chloride binding aspects as well as recent advances made in the applications of LDHs in concrete. The chloride binding aspects of LDH in concrete are critically reviewed but other related effects such as influence of LDH addition on mechanical properties, dosage, effect on microstructure etc. are also discussed.

\section{Chloride Induced Steel Corrosion in Concrete}

Concrete is the most widely used engineering material $[29,30]$ which is prepared by mixing together cement binder, fine and coarse aggregates and water. After the mixing phase the concrete is able to take any desired shape upon hardening. The resulting concrete is very good to resist compressive stresses but does not display similar capabilities under tensile loading. To improve this, steel reinforcement is embedded in the concrete which is able to take tensile stresses and also provide confinement to concrete. Concrete itself being non-metallic in nature is not susceptible to corrosion, however it is the embedded metallic steel that is susceptible to corrosion and can lead to structural failure under prolonged exposure in corrosive environments.

Concrete is an alkaline environment [31-33] and the alkalinity has a protective effect towards embedded steel bars as it helps in developing a thin protective layer on the steel surface, usually referred to as the passive layer [34,35]. This passive layer is very thin, usually a few nanometers in thickness [36] and protects the steel rebar from corrosion. At this stage, the rebar is said to be passivated and the structure is said to be in the initiation stage [7]. The porous nature of the concrete [37] allows chloride ions to pass through. In due time, chloride ions reach the steel concrete interface [38]. An accumulation of chloride ions on the rebar surface beyond a critical threshold can destroy the passive layer. At this stage the rebar is said to be depassivated [39] and the structure is said to be in its propagation stage, as shown in Figure 1. The amount of chloride ions which can cause depassivation of steel is termed critical chloride threshold [40]. A faster ingress of chloride can shorten the initiation stage of the structure and accelerate depassivation stage leading to shorter service life of structure. On the other hand, a slower or reduced ingress of chlorides can increase the service life of structure. Innovative cement additives that can slow down the chloride ingress can lead to an extension of the initiation stage. Similarly, corrosion inhibitors can reduce the severity of corrosion and mitigate structural deterioration, see Figure 1.

Once the critical threshold is reached at the steel-concrete interface, the onset of corrosion is said to take place. This leads to the formation of active anodic regions, and in the presence of moisture and oxygen lead to the formation of a corrosion cell between anodic and cathodic parts of the rebar. As corrosion progresses, rust products are generated as a result of corrosion reactions. Rust products are more expansive than parent steel [41] and their accumulation at the steel-concrete interface generates considerable internal pressure leading to micro-cracking of concrete [42,43]. As time progresses, microcracks coalesce to form visible macro-cracks which eventually can lead to the deterioration of structural elements [44]. 


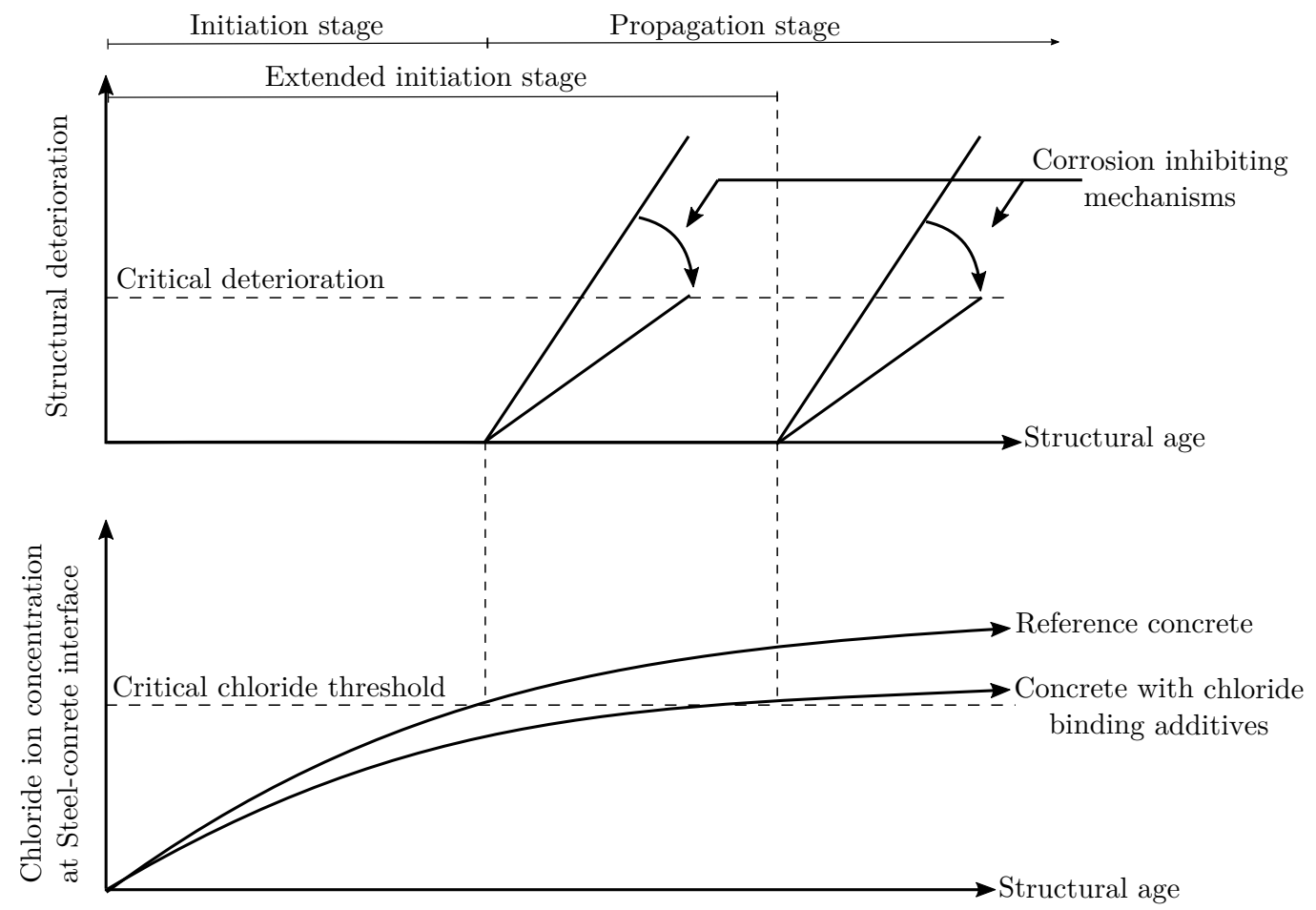

Figure 1. Schematic representation of service life stages of concrete structures under chloride induced corrosion and associated chloride profiles based on modified Tuutti's diagram $[7,40]$.

\section{Chloride Binding in Concrete}

The transport of chloride ions in concrete matrix occurs through the pore network $[45,46]$. It is widely accepted that a considerable fraction of chloride ions are physically and chemically bound to the surrounding cementitious matrix [47]. These chlorides are usually named in the literature as bound chlorides. The rest of the chlorides are termed free chlorides and move freely inside the concrete pore system. It is the accumulation of free chloride on the steel concrete interface that is responsible for corrosion initiation [48]. On the other hand, the capability of concrete to bind chloride ions as well as ratio of bound chlorides to free chlorides are vital parameters regarding performance and service life estimation. Increasing the amount of bound chlorides in concrete can help in extending the time to reach the critical chloride concentration [40] on the steel concrete interface (Figure 1).

A significant contribution of bound chlorides is attributed to tricalcium aluminate $\left(\mathrm{C}_{3} \mathrm{~A}\right)$ and tetracalcium alumino-ferrite $\left(\mathrm{C}_{4} \mathrm{AF}\right)$ content in binders $[49,50]$ as they lead to the formation of aluminate monosulphate (AFm) phases upon hydration. AFm is able to chemically bind chlorides in concrete [51,52] forming Friedel's salt which can be chemically expressed as $3 \mathrm{CaO} \cdot \mathrm{Al}_{2} \mathrm{O}_{3} \cdot \mathrm{CaCl}_{2} \cdot 10 \mathrm{H}_{2} \mathrm{O}$ or its iron analogue $3 \mathrm{CaO} \cdot \mathrm{Fe}_{2} \mathrm{O}_{3} \cdot \mathrm{CaCl}_{2} \cdot 10 \mathrm{H}_{2} \mathrm{O}$. Depending on the concentration of chloride ion, other salts may be formed such as Kuzels salt $3 \mathrm{CaO} \cdot \mathrm{Al}_{2} \mathrm{O}_{3} \cdot 0.5 \mathrm{CaCl}_{2} \cdot 0.5 \mathrm{CaSO}_{4} \cdot 11 \mathrm{H}_{2} \mathrm{O}$ [53]. Florea et al. [51] quantified the chloride binding of different $\mathrm{AFm}$ phases such as monosulphate-AFm $\left(3 \mathrm{CaO} \cdot \mathrm{Al}_{2} \mathrm{O}_{3} \cdot \mathrm{CaSO}_{4} \cdot 14 \mathrm{H}_{2} \mathrm{O}\right)$ and hydroxy-AFm $\left(3 \mathrm{CaO} \cdot \mathrm{Al}_{2} \mathrm{O}_{3} \cdot \mathrm{CaOH}_{2} \cdot 12 \mathrm{H}_{2} \mathrm{O}\right)$ and observed different binding capacities depending upon external $\mathrm{Cl}^{-}$level.

On the other hand, the physical binding of $\mathrm{Cl}^{-}$in terms of surface adsorption occurs on the calcium silicate hydrate (CSH) interlayers by replacement of loosely bound $\mathrm{OH}^{-}$ion by $\mathrm{Cl}^{-}$thereby maintaining electroneutrality in the system. This physical adsorption mostly proceeds on the external layers of CSH layers [54]. Tang et al. [55] reported that the amount of CSH gel is mainly responsible for the amount of chloride binding [49] whereas Florea et al. [51] considered that CSH binds fewer chlorides than AFm phases. Furthermore, it is to be noted that the chloride binding capacity varies depending on the type of the cation present in the salt [56]. 
Additionally, supplementary cementitious materials (SCM) are added to concrete mixes to replace cement binder, usually as a replacement. One of the motivations behind replacement of cement binder by SCM is to reduce the carbon footprint of concrete industry and also to impart additional functionality to concrete [57]. As such, fly ash (FA), ground-granulated blast furnace slag (GGBFS), silica Fume(SF), metakaolin (MTK) etc. are used as SCM in concrete. Likewise, the addition of SCM also significantly effects the chloride binding properties of concrete. It is now widely accepted that chloride binding increases with the addition of FA, GGBFS [58,59], MTK [57] whereas the addition of SF reduces the amount of bound chlorides [49]. It is believed that ion exchange mechanism is responsible for the chloride binding.

In the last two decades, Layered Double Hydroxides have emerged a new class of nanoscale engineered concrete additives which can impart additional functionality to concrete. Although the role of LDHs in concrete technology is widespread in different areas, the most outstanding application of LDH is its ability to trap anions (possibly aggressive ions such as $\mathrm{Cl}^{-}$) from the environment and release a tailored anion in its place (like a corrosion inhibiting anion such as $\mathrm{NO}_{2}{ }^{-}$) via a controlled release mechanism. This property has been termed as "Self-Protection" of concrete and can result in an extended corrosion initiation stage as well as a reduced corrosion degradation in the propagation stage as shown schematically in Figure 1. This review highlights the most notable applications of LDH in concrete technology with a detailed insight into the chloride binding capacity of concrete with LDH.

\section{Layered Double Hydroxides}

Layered double hydroxides are nano-materials with a layered structure as shown in Figure 2. The layers themselves are formed of bivalent and trivalent cations coinciding with the layered structure of Brucite $\mathrm{Mg}(\mathrm{OH})_{2}$. The layers in LDHs are positively charged in nature as they are formed due to replacement of some divalent cations by trivalent cations during their formation. This leads to a charge imbalance and in order to compensate this positive charge excess, the interlayers can hold negatively charged anions, as well as some loosely bound $\mathrm{OH}^{-} / \mathrm{H}_{2} \mathrm{O}$ in between the layers. LDHs can be represented by the general formula $\mathrm{M}_{1-\alpha}^{I I} \mathrm{M}_{\alpha}^{I I I}(\mathrm{OH})_{2}\left(\mathrm{X}^{n-}\right)_{\alpha / n} \cdot \mathrm{mH}_{2} \mathrm{O}$ with $\alpha$ ranging from $0.2-0.33$, $\mathrm{m}$ equal to $1-3 \alpha / 2, \mathrm{M}^{I I}$ is the divalent cation (e.g., $\mathrm{Mg}^{2+}, \mathrm{Ni}^{2+}, \mathrm{Zn}^{2+}, \mathrm{Ca}^{2+}$ ), $\mathrm{M}^{I I I}$ is the trivalent cation (e.g., $\mathrm{Co}^{3+}, \mathrm{Al}^{3+}, \mathrm{Fe}^{3+}, \mathrm{Ga}^{3+}$ ) etc. and $\mathrm{X}^{n-}$ is the exchangeable anion with valency $n$ present in interlayer galleries and can be $\mathrm{CO}_{3}^{2-}, \mathrm{SO}_{4}^{2-}, \mathrm{Cl}^{-}, \mathrm{OH}^{-}, \mathrm{NO}_{3}{ }^{-}, \mathrm{NO}_{2}{ }^{-}$etc. The molar ratio of $\mathrm{M}^{I I}$ to $\mathrm{M}^{I I I}$ is in the range between 2 to $4[27,60]$. The interlayer anion in $\mathrm{LDH}$ galleries can be easily exchanged with an anion present in the external environment. Due to this ion exchange property, LDHs are also called anionic clays [61]. This unique property makes LDH a very versatile material as they can help in sequestration of anions from the environment with a possibility of releasing a tailored anion in its places. LDH can therefore be used as a potential additive for the capture of corrosion causing species and release of corrosion inhibiting anions in cementitious environments. LDH can be synthesized in powdered form and added as a percentage of the binder content or in the slurry form wherein corrections to the total $\mathrm{w} / \mathrm{c}$ ratio should be made considering the amount of water originally present in the slurry.

The ion exchange property of LDH has been used for a wide range of applications across different disciplines such as drug delivery systems [62], treatment of stomach ulcers [63], genetic science [64], removal of toxic anions from water [65-68], protective coatings against corrosion on metal surfaces [69], cleansing of sea water to obtain usable cultivation water [70], removal of pollutants [71], asphalt mixes with deicing property [72] etc. are a few noteworthy applications. In concrete technology, studies on LDH as a cement additive began towards the end of 20th century, and in recent years, LDHs have gained a considerable popularity as concrete additives. 


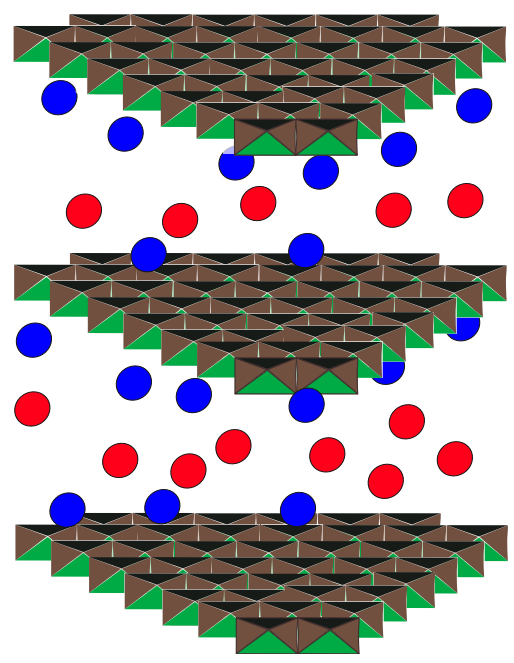

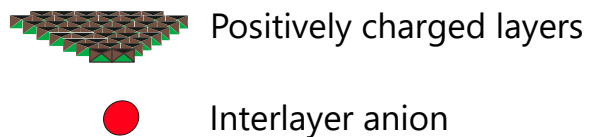

- Attached $\mathrm{OH} / \mathrm{H}_{2} \mathrm{O}$

Figure 2. Schematic representation of Layered Double Hydroxide (LDH) structure.

\subsection{Preparation Methods}

LDHs can be prepared by various techniques. The easiest and commonly used is the co-precipitation method. In this method aqueous solution of desired divalent and trivalent metallic salts are slowly added into a mixer containing water and allowed to simultaneously co-precipitate in an alkaline environment. The $\mathrm{pH}$ is held constant by adding an alkaline solution of desired $\mathrm{pH}$ [73]. Usually co-precipitation is done in the $\mathrm{pH}$ range of 8-10 [74]. Another simple method is the ion-exchange method in which a pre-synthesised LDH precursor is modified by allowing it to conduct ion exchange of its interlayer anions with desired guest anion present in the external solution. It is important to note that the ion-exchange method is strictly influenced by the affinity of LDH towards the guest anion [75,76], the type of the exchange medium [77], temperature [78] , $\mathrm{pH}$ value of the medium [79] as well as the chemical composition of the LDH itself [80]. Both the co-precipitation method and the ion-exchange method can be used to synthesize LDH with corrosion inhibiting ions, e.g., $\mathrm{NO}_{2}{ }^{-}$. Using oxide of divalent cation and salt of trivalent cation, Zuo et al. [81] was able to directly synthesize $\mathrm{LDH}-\mathrm{NO}_{2}$ in an alkaline environment containing $\mathrm{NaNO}_{2}$. Another method of obtaining the same $\mathrm{LDH}$ would be to first synthesize $\mathrm{LDH}-\mathrm{NO}_{3}$ and then allow the $\mathrm{LDH}$ to conduct ion exchange with an environment containing $\mathrm{NO}_{2}{ }^{-}$ions. Both the synthesis paths provide different quantities of intercalated $\mathrm{NO}_{2}{ }^{-}$in $\mathrm{LDH}$ [81].

Another method that is commonly followed is the calcination $[82,83]$ method where LDH is heated to high temperatures in order to remove interlayer water $/ \mathrm{OH}^{-}$and interlayer anions, thereby losing it layered structures and forming amorphous metallic oxides. Upon rehydration the LDH is able to reconstruct its structure using its "memory effect" property [84] upon exposure to water and also intercalate new anions which were not present in the parent LDH [80]. Apart from these preparation procedures, other methods of synthesis do exist $[85,86]$ and the interested reader is directed to the work of He et al. [80]. LDHs also occur freely in nature. Hydrotalcite is a naturally occurring mineral and belongs to the family of $\mathrm{LDH}$, being known since the $19^{\text {th }}$ century. Chemically, it can be represented as $\mathrm{Mg}_{6} \mathrm{Al}_{2}(\mathrm{OH})_{16}\left[\mathrm{CO}_{3}\right] \cdot 4 \mathrm{H}_{2} \mathrm{O}$. It was first discovered in Norway and reported by German-Austrian chemist Carl C. F. Hochstetter in 1842 [87].

LDHs are not strange to concrete chemistry either. The hydration of cement binder is accompanied by the formation of a family of hydrated calcium aluminate phases (AFm) which belong to the broader class of the LDH family. According to Matschei et al. [88], in some blended cements AFm phases content can be upto $20 \%$. AFm phases just like synthetic LDH can be represented by the formula $\left[\mathrm{Ca}_{2}(\mathrm{Al} / \mathrm{Fe}) \mathrm{OH}_{6}\right] \cdot A \cdot \mathrm{xH}_{2} \mathrm{O}$ with $A$ as the exchangeable anion [89]. AFm phases resembling LDH compounds consist of brucite like sheets with some divalent cations replaced with trivalent cations such as $\mathrm{Fe}^{3+}$ or $\mathrm{Al}^{3+}$. Similar to $\mathrm{LDH}$, these AFm show anion exchange capabilities with more affinity 
to divalent anions such as $\mathrm{CO}_{3}^{2-}$, $\mathrm{SO}_{4}^{2-}$ etc. than mono-valent anions $\mathrm{Cl}^{-}, \mathrm{OH}^{-}$etc. Additions of ground granulated blast furnace slag (GGBFS) as SCM also leads to the production of hydrotalcite like phases [90,91] which has chloride binding properties [92]. Studies of Kayali et al. [93] revealed hydrotalcite formation exists in cement blends with GGBFS. Formation of hydrotalcite lead to reduced chloride ingress due to ion exchange capabilities of these LDH.

\subsection{Ion Exchange Property Of LDH}

As mentioned previously, the ion exchange property is the most vital property concerning the application of LDH in concrete. Figure 3 (left) depicts the ability of LDH to capture ions from the environment. In this test $1 \mathrm{~g}$ of $\mathrm{LDH}$ was exposed to $50 \mathrm{mM}^{-} \mathrm{Cl}^{-}$containing solution at time $(\mathrm{t}=0 \mathrm{~s})$ under stirring conditions. Chloride ion concentration was constantly monitored for $300 \mathrm{~s}$ after LDH immersion. It is evident that LDH was able to reduce the $\mathrm{Cl}^{-}$concentration from the surrounding solution. Figure 3 (right) depicts the ion release property of LDH. In this work from Tedim et al. [94] release of $\mathrm{NO}_{3}{ }^{-}$ion from $\mathrm{Zn}-\mathrm{Al}-\mathrm{NO}_{3}$ due to step wise exposure to $\mathrm{Cl}^{-}$ions is presented. This confirms the ion release property of LDH. An in-depth explanation on the ion-exchange property is presented later. Apart from the ion exchange property, LDHs posses numerous other interesting properties which are of vital importance in other branches of science and technology. The interested reader is referred to the extended literature on LDH by Evans et al. [74], Forano et al. [95] and Kuang et al. [96].
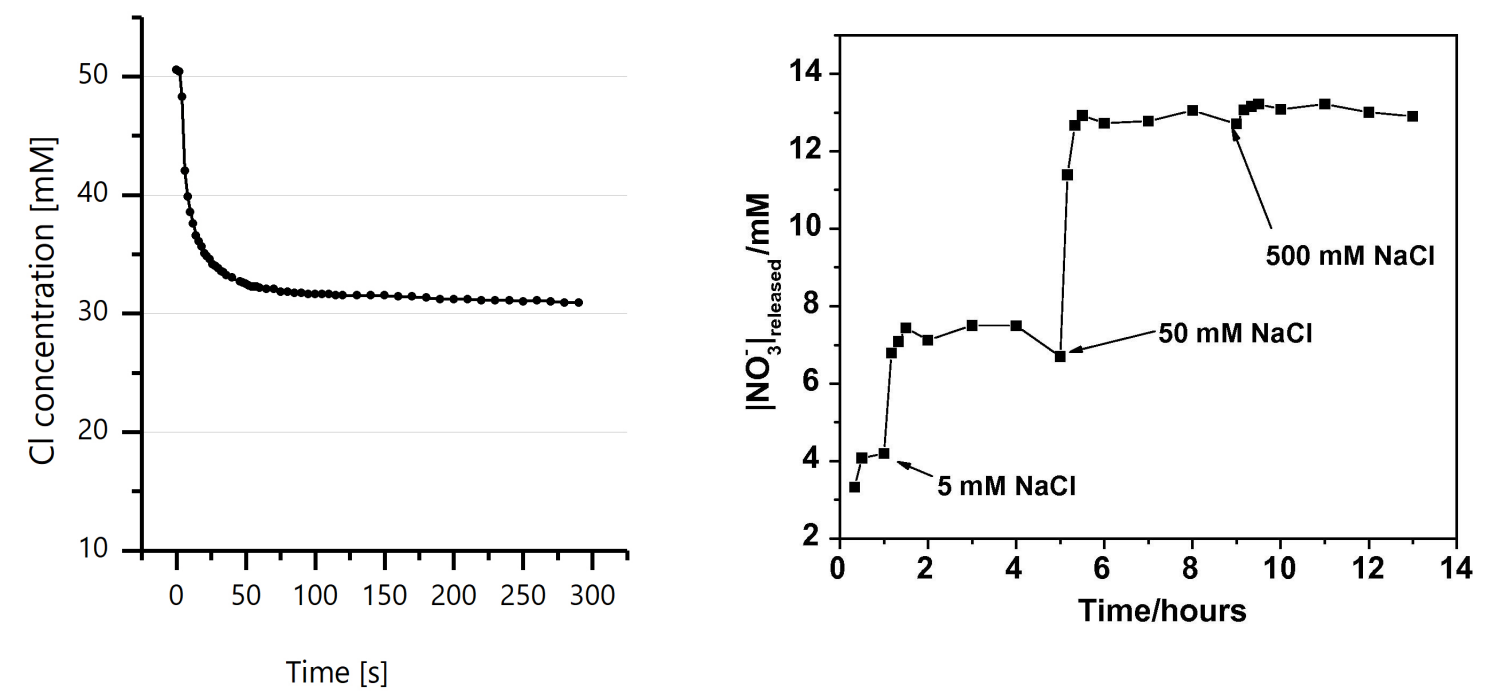

Figure 3. (Left) Decrease in chloride ion concentration due to addition of $\mathrm{Zn}-\mathrm{Al}-\mathrm{NO}_{2}$ to the solution containing $50 \mathrm{mM}$ of initial chloride concentration. (Right) Release of $\mathrm{NO}_{3}{ }^{-}$ion from $\mathrm{Zn}-\mathrm{Al}^{-} \mathrm{NO}_{3}$ after exposure to $\mathrm{Cl}^{-}$ion (reprinted from [94] with permission from Elsevier).

\section{Compatibility of Ldh with Cementitious Environments}

LDHs have been mostly used in concrete in order to improve its chloride resistance by harnessing the ion exchange property of LDH. However, prior to discussing the ion exchange property and chloride encapsulation of $\mathrm{Cl}^{-}$by $\mathrm{LDH}$ in cement/concrete, it is important to understand the compatibility of LDH with cement. In this section, compatibility with cement, influence on mechanical properties and the effect of dosage on the microstructure are discussed. The discussion is based on a critical analysis of recently published literature in this field.

\subsection{Effect on Mechanical Properties}

LDH are nanoparticles which are reported to refine the microstructure of concrete without causing a substantial increase in porosity. As LDH is usually added in its powdered form to concrete mixes, 
these nanoparticles are uniformly distributed in the matrix and in the course of cement hydration process, $\mathrm{LDH}$ can provide additional nucleation sites for cement hydration. This in turn can promote growth of CSH gel into the voids, thereby refining the microstrucutre. Additionally, the particles themselves act as micro-fillers or micro-aggregates inside the cementitious matrix. Depending on the type of LDH in use, it can have a positive effect on the mechanical properties of concrete especially its compressive strength, see Table 1. LDHs have hexagonal platelet like structures and if they are able to retain their structure in mature concrete, the resulting concrete can also show enhanced flexural strength as these thin LDH platelets can act as micro-beam elements [97] between cementitious materials and therefore help in an efficient transfer of bending stresses. Table 1 presents a compilation of compressive and flexural strength enhancement of concrete together with type of LDH and dosages used by different authors.

Table 1. Effect of addition of LDH on the mechanical properties of concrete. CS: Compressive strenght; FS: Flexural strength.

\begin{tabular}{|c|c|c|c|c|c|c|c|}
\hline $\begin{array}{l}\text { LDH } \\
\text { Type }\end{array}$ & $\begin{array}{c}\text { Cement } \\
\text { Type }\end{array}$ & Dosage * & \multicolumn{2}{|c|}{ Concrete Properties } & Age & Year & Ref. \\
\hline $\mathrm{CaAl} \mathrm{LDH}$ & CEM 42.5 & $1-5 \%$ & $+6 \%(2 \% \mathrm{LDH})$ & - & $28 \mathrm{~d}$ & 2009 & Xu et al. [98] \\
\hline MgAl LDH & [82] & $8.5 \%$ & $\sim-2 \%$ & - & $28 \mathrm{~d}$ & 2014 & Yoon et al. [82] \\
\hline MgAl pAB & CEM I $42.5 \mathrm{~N}$ & $5-10 \%$ & $-17.2 \%(10 \% \mathrm{LDH})$ & $-21.38 \%(10 \% \mathrm{LDH})$ & $28 \mathrm{~d}$ & 2015 & Yang et al. [100] \\
\hline LiAl LDH & [102] & $1-3 \%$ & $+25 \%$ & - & $7 d$ & 2017 & Haiyan et al. [102] \\
\hline $\mathrm{CaAl} \mathrm{NO} 3$ & CEM I 52.5R & 0.5-2 Vol. & $+17 \%(1 \% \mathrm{LDH})$ & $+55 \%(1 \% \mathrm{LDH})$ & $28 \mathrm{~d}$ & 2018 & Qu et al. [97] \\
\hline $\mathrm{MgAl} \mathrm{CO} 3$ & CEM I 52.5 & $1-3 \%$ & $\sim+3.5 \%(3 \% \mathrm{LDH})$ & - & $28 \mathrm{~d}$ & 2018 & Wu et al. [103] \\
\hline MgAl LDH & [104] & $1-2 \%$ & $+8.2 \%(1 \% \mathrm{LDH})$ & - & $56 \mathrm{~d}$ & 2018 & Chen et al. [104] \\
\hline LiAl LDH & [105] & $0.5-1.5 \%$ & $+46.2 \%(1 \% \mathrm{LDH})$ & - & $28 \mathrm{~d}$ & 2019 & Zou et al. [105] \\
\hline
\end{tabular}

* In mentioning the dosage, no distinction has been made for LDH added as $\%$ of binder content or $\%$ of binder replacement or $\%$ of total cementitious materials.

From Table 1, it can be observed that Ca based LDH has a profound positive effect on mechanical properties whereas multiple entries report a Mg based $\mathrm{LDH}$ to have a negative or inconclusive effect on mechanical properties. Qu et al. [97] used Ca based LDH and observed a strong increase in the compressive strength and flexural strength in samples with LDHs as compared with reference samples. A $17.2 \%$ increase in compressive strength was observed in samples with $1 \%$ dosage of LDH (mean particle size $3.2 \mu \mathrm{m}$ ) but only $1.7 \%$ strength increase for $2 \% \mathrm{LDH}$, see Figure 4 . It can be inferred that a dosage of up to $2 \%$ could be safe for application in concrete and will not drastically affect the compressive strength. Higher dosages can lead to agglomeration of the particles and may not play any significant role in enhancing the strength of concrete. The particle size is also important as smaller particles can have a filler effect and refine microstrucutre leading to higher compressive strengths despite only a slight change in porosity. In the same study, the flexural strength increased with addition of LDH. The particle size was also a dominating factor as finer the particle, higher was the strength increase. However, as dosage of LDH (mean particle size $3.2 \mu \mathrm{m}$ ) increased from $1 \%$ ( $+55 \%$ increase) to $1.5 \%(+44.3 \%$ increase) and $2 \%(+40.5 \%$ increase $)$, the flexural strength started decreasing although still considerable higher $\sim>40 \%$ than reference sample, see Figure 4 . The authors concluded that overall dosages up to $2 \%$ can have a positive influence on mechanical properties of concrete. Higher dosages than $2 \%$ can be the threshold for particle agglomeration [97].

Contrary to the studies of Qu and colleagues [97], Yang et al. [100] used Mg based LDH (see Table 1) and reported a trend of decreasing compressive strength as dosage of LDH increased, for all specimens at all ages. The strength decrease was still in the acceptable range in samples with up to $5 \% \mathrm{LDH}$. The negative effect on compressive strength due to addition of Mg LDH was also reported in the studies of Duan et al. [99]. However the results were found to be inconclusive as with $1 \% \mathrm{LDH}$, the compressive strength slightly increased but remained almost the same with $2 \% \mathrm{LDH}$. In another 
study, Xiong et al. [101] used calcined Mg-Al-LDH and reported a reduced compressive strength for mortars with LDH. A $28 \mathrm{~d}$ strength test revealed a decrease of about $25 \%$ in the compressive strength. Studies by Yoon et al. also reported a slight decrease in compressive strength [82].
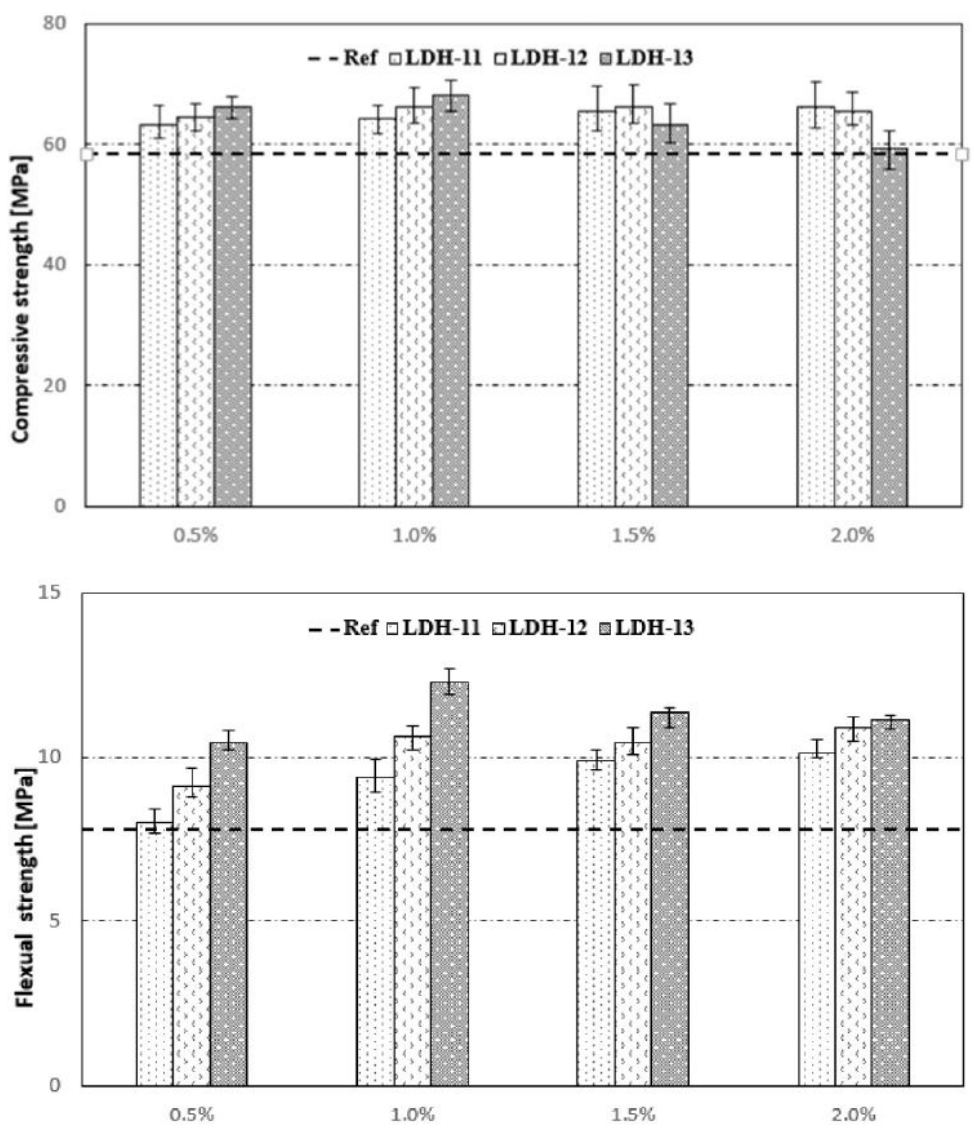

Figure 4. LDH dosage and effect on compressive and flexural strength. LDH-11, LDH-12, LDH-13 refer to mean particle size of $9.5 \mu \mathrm{m}, 6.3 \mu \mathrm{m}$ and $3.2 \mu \mathrm{m}$ respectively. Reprinted from [97] with permission from Elsevier.

\subsection{Effect of LDH Dosage on Microstructure}

Different authors who have worked with LDH have resorted to different dosages of LDHs for applications in concrete. Usually a range of values is evaluated and higher dosages are used with the aim of improving a desired property of concrete or to check the ultimate threshold of the dosage in relation to the desired property. However, while one property might improve, addition of LDH can affect other important properties of mortars and concrete. One of the predominant effects is on porosity as found by Yang et al. [100] where porosity increased with the increasing dosage of LDH. This can have detrimental effect on other associated concrete properties such as chloride penetration. Increase of porosity can lead to faster ingress of chloride ions upon exposure and shorten the corrosion initiation stage. As the porosity increases the chloride ingress can increase despite high chloride binding. It is important to emphasize that more parameter studies must be conducted while selecting a suitable LDH dosage for applications in concrete, as dosage can have a big impact on the properties on concrete mixes.

Previous studies by Qu et al. [97] have revealed that low dosages of LDH do not have a strong influence on porosity increase. They observed that dosages up to 2 vol.\%, are a good choice for incorporation of LDHs in concrete. Moreover, additions of nanoparticles like LDH up to a certain dosage can refine the microstrucutre without changing the total porosity which is advantageous towards chloride durability. This has also been reported by other authors working with nano-additives 
for concrete [106,107]. The use of LDH for pore refinement was carried out by Duan et al. [99]. They used Mg-Al-LDH in raw and calcined form in cement pastes and concretes (The dosage is presented in Table 1) and observed pore refinement due to addition of $\mathrm{Mg}$ based LDH.

\subsection{Effect ON Hydration}

LDHs have also been used to modify the hydration kinetics of concrete. It is generally believed that the addition of nano-particles can lower the energy barrier for precipitation reactions taking place in liquid state and also provide additional nucleation sites for cement hydration due to their very small size and very high surface area [98,108,109]. In a recent study, Xu et al. [98] observed by using XRD that adding nano-particles of Ca based LDH accelerated the formation of hydration products, notably CSH. This in turn resulted in a increase of early age strength development. The authors used Ca-Al-Cl LDH in their study and it is well known that both $\mathrm{Ca}^{2+}$ and $\mathrm{Cl}^{-}$are the most accelerating cation and anion respectively [110]. One can therefore attribute the accelerating effect of LDH addition to the role of $\mathrm{Ca}^{2+}$ and $\mathrm{Cl}^{-}$ions. The underlying mechanisms regarding effect of various ion on the hydration kinetics are not fully understood and the reader is directed to the works of Myrdal [110] for further reading.

Additionally, $\mathrm{Xu}$ et al. conducted in situ XRD analysis of cement mortars with and without $\mathrm{Ca}^{2+}$ based LDH and observed that higher amounts of CSH gel are formed at early ages confirming the strength increase effect and hydration acceleration property of Ca-Al-Cl LDH. XRD analysis revealed higher intensity of CSH peaks occurring at early ages and this effect was amplified as concrete aged, see Figure 5. Li based LDH can also potentially be used to accelerate hydration [105,111] and impart early strength to concrete although the mechanism is unclear. Haiyan et al. [102] observed that setting time was reduced to almost half by using 3\% addition of Li based LDH but they did not comment on the working mechanism. Moreover the authors also reported a sharp increase in the early strength development for samples with Li based LDH, see Table 1. Mg-based LDH have also been reported to have a slight accelerating effect on cement hydration. In the studies of Wu et al. [103], the authors observed that a 3\% Mg LDH addition had an accelerating effect on cement hydration. They attributed this effect to the reaction of sulphate ions from gypsum with LDH that could potentially accelerate cement hydration.

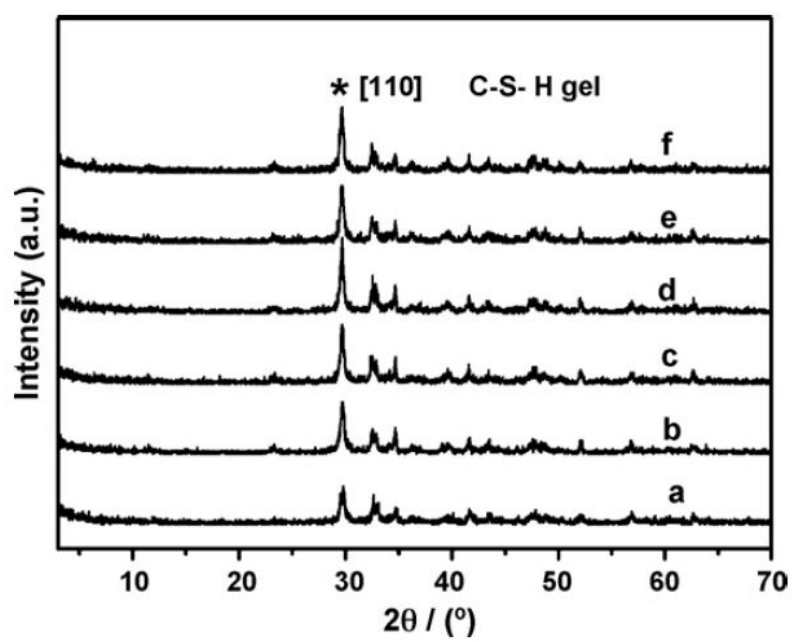

Figure 5. In situ XRD patterns of cement mortar (a) without and (b-f) with LDHs additives after different aging times: (b) 6 min; (c) 1 d; (d) 3 d; (e) 7 d; (f) 28 d. Symbol of * shows the characteristic [1 110$]$ reflection peak of C-S-H gel. Reprinted from [98] with permission from Elsevier.

On the other hand, LDH can also decelerate or retard cement hydration. Recent studies by Gomes et al. [25] reveled that addition of $\mathrm{ZnAl} \mathrm{LDH} \mathrm{had} \mathrm{a} \mathrm{decelerating} \mathrm{effect} \mathrm{on} \mathrm{hydration} \mathrm{processes}$ 
and early strength development. They used a dosage of $2-5 \%$ LDH to cement with an average particle size of $25 \mu \mathrm{m}$ in cement pastes. The samples depicted an unusually long hardening time. The authors attributed this effect to the partial dissolution of $\mathrm{ZnAl} \mathrm{LDH}$ in high alkaline $\mathrm{pH}$ which releases $\mathrm{Zn}^{2+}$ ions in to the pore solution. $\mathrm{Zn}^{2+}$ ions are known to have a strong retarding effect on cement hydration $[112,113]$. The presence of $\mathrm{Zn}^{2+}$ ions in the early stages of cement hydration can lead to formation of $\mathrm{Zn}-\mathrm{Ca}$ complexes such as $\mathrm{Ca}\left(\mathrm{Zn}\left(\mathrm{OH}_{3}\right)_{2}\right) \cdot 2 \mathrm{H}_{2} \mathrm{O}$ which in turn reduce the concentration of $\mathrm{Ca}^{2+}$ and $\mathrm{OH}^{-}$in the pore solution thereby retarding the hydration reactions [114]. Gomes et al. [25] also observed that particle size matters because bigger agglomerates $\sim 125 \mu \mathrm{m}$ did not affect the hydration. This can be understood considering the reduced surface area of bigger agglomerates which do not suffer so significant dissolution as compared to finer particles.

\section{Ion Exchange Property and Self Protection of Concrete}

LDHs by their nature and unique chemical structure are able to exchange anions present in the external environment by an anion from their inter layers. This process is governed by the difference of chemical potential in the direction of decrease of Gibbs free energy. In order to maintain electro-neutrality, a charge balance is maintained before and after the ion exchange $[26,27,81,94,115-124]$. This property has been termed as the ion exchange property of LDH [122]. As such LDHs can act as anion adsorbents or anion scavengers, in different environments [125]. Furthermore, as LDHs can be synthesised with different cations and exchangeable anions, this makes them a very versatile class of materials which can be tailored to deliver a desired anion and capture selective ions from the environment. Figure 6 shows a schematic representation of the structure of LDH with interlayer anions. Upon exposure to external anions, the LDH is able to capture these anions and the process is accompanied with the release of interlayer anions. This property has been exploited in corrosion mitigation of concrete structures where functional LDH is used to conduct chloride ion capture and simultaneously deliver a corrosion inhibiting anion. Not only does this prolong/extend the corrosion inhibition stage but also protects the steel from initiating corrosion processes. This dual benefit has been termed as self-protection process in concrete.

The ion exchange property of LDH is also used to produce LDH with a desired anion by exposing LDH to a solution of this anion. The desired anion is captured by LDH by replacing the anion originally present in its galleries. The LDH is then usually centrifuged and separated from the filtrate, washed and dried. It must be noted that anion uptake is governed by many factors such as temperature [78], particle size [97], anion type [126,127], anion charge and size [128,129] etc.

Calcined LDH has also been used to conduct ion capture in concrete [103]. Calcination of LDH results in the collapse of the layered structure of LDH. In this process the interlayer anions and the attached $\mathrm{OH}^{-} / \mathrm{H}_{2} \mathrm{O}$ molecules are lost. Upon exposure to moisture and external anions, the LDH is able to regenerate its layered structure with new guest anions and water molecules as shown schematically in Figure 6. The use of calcined LDH in concrete is best demonstrated by the work of Duan et al. [130] where authors used calcined Mg LDH to increase the carbonation resistance of concrete and reported very promising results.

During the ion exchange process, the ion uptake is governed by thermodynamics as it represents a heterogeneous equilibrium between chloride ions present in solid species (LDH) and the $\mathrm{Cl}^{-}$ ions present in the pore solution at equilibrium. Studies report that higher the external $\mathrm{Cl}^{-}$ion concentration, higher is the $\mathrm{Cl}^{-}$binding due to LDH. As such, the binding behavior can be represented by Freundlich or Langmiur type isotherms (Figure 7 right). In both these isotherms, uptake increases as free chloride ion concentration increases. Furthermore, for each type of $\mathrm{LDH}$, its ion exchange property is governed by many factors. The most important factor ruling ion exchange is the selectivity series for that LDH. LDH is able to conduct preferential ion exchange based on the order of ions in the selectivity series. Chen et al. [131] concluded that for $\mathrm{CaAlNO}_{3} \mathrm{LDH}$ in alkaline environment, the selectivity series is $\mathrm{Cl}^{-}>\mathrm{OH}^{-}>\mathrm{NO}_{3}{ }^{-}$whereas Costa et al. [127] computationally derived the selectivity series for $\mathrm{ZnAl} \mathrm{LDH}$ to be $\mathrm{CO}_{3}^{2-}>\mathrm{OH}^{-}>\mathrm{F}^{-}>\mathrm{Cl}^{-}>\mathrm{Br}^{-}>\mathrm{NO}_{3}^{-}$. Although, in general the 
selectivity series governs the ion exchange, the series order might change if the concentration of one of the non-preferential anions is too high in the external environment as compared to the preferred anion in the series. According to the selectivity series, $\mathrm{CO}_{3}{ }^{2-}$ ions are very stable inside $\mathrm{LDH}$ and difficult to replace by ion exchange. However, studies by Iyi et al. [60] concluded that LDH containing carbonate ions can even be de-carbonated by a non-preferential anion such as $\mathrm{Cl}^{-}$, if $\mathrm{Cl}^{-}$is present in a very high concentration. In this case, the anion present in high concentration can potentially force its uptake. The size of the anion also governs ion uptake as Iyi et al. [60] was not able to replace carbonate ion using a high concentration of iodide ions. The ion exchange property of LDH prefers smaller sized anions over larger anions. However, as the ion exchange is based on charge conservation, LDHs are particularly affine to divalent anions as compared to monovalent anions with carbonate anions being the most preferred anion for most of the LDHs. As such, LDHs have been used to increase the carbonation resistance of concrete [132] as they can efficiently capture carbonate ions.

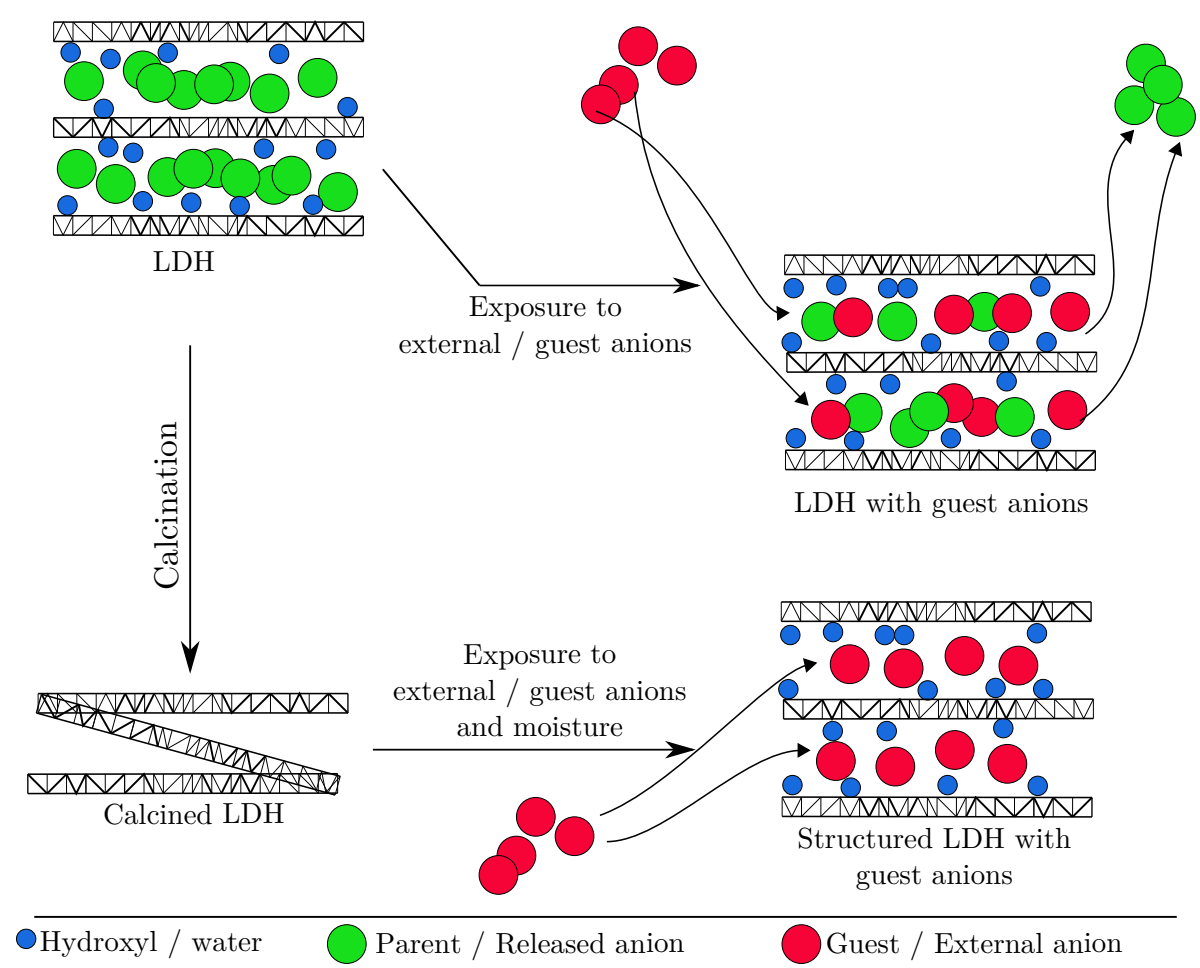

Figure 6. Schematic representation of the LDH structure and ion exchange/capture mechanism.

\subsection{Chloride Entrapment and Corrosion Performance}

The ion exchange property of LDH has been used extensively in the corrosion protection of concrete. Many authors have used LDH to conduct additional chloride binding in concrete as well as controlled delivery of corrosion inhibiting anions. Numerous applications also report on the use of LDH for mitigation of carbonation induced steel corrosion in concrete. Table 2 presents a list of recent works where LDH has been used an as anion exchanger focusing either on capture of chloride or carbonate ion, as well as delivery of corrosion inhibitor. Based on a detailed literature study summarized in Table 2, only a few of the reported studies are conducted in concrete and literature reports a majority of studies in salt solutions and concrete pore solutions. Table 2 also presents the preparation methods, target application exploiting ion exchange property as well as LDH dosages used. This table can aid researchers and engineers to decide on starting materials and dosages of LDH. Moreover, it is interesting to note the disparity in dosages that different authors have used in various investigations. The reported dosage varies from $0.2 \mathrm{wt} . \%$ [133] to 10\% [100]. Attention must be paid to avoid high LDH dosage as it can strongly affect the properties of mortars and concrete, as mentioned earlier. Higher dosages can indeed increase the chloride binding capacity as more LDH will be present 
to capture $\mathrm{Cl}^{-}$but on the other hand, higher dosages can certainly increase the porosity of concrete which facilitates $\mathrm{Cl}^{-}$ingress.

$\mathrm{LDH}$ is able to capture $\mathrm{Cl}^{-}$ions from the pore solutions lessening its concentration. Zhonghe et al. [134] studied Mg-Al- $\mathrm{NO}_{3}$ and $\mathrm{Mg}-\mathrm{Al}-\mathrm{CO}_{3} \mathrm{LDH}$ and observed a higher chloride binding capacity when LDH was present. The binding capacity was lower with the carbonate based LDH because this ion is difficult to replace. Yoon et al. [82] used commercially available Mg- Al LDH and calcined it at $450{ }^{\circ} \mathrm{C}$. The resulting $\mathrm{LDH}$ was applied as a chloride entrapping additive with a $8.5 \mathrm{wt} . \%$ dosage in cement pastes and the authors reported enhanced chloride uptake capabilities. Based on their results, the authors confirmed the positive benefits of LDH in increasing the service life of concrete structures.

Although chloride capture due to LDHs has been mostly due to the ion exchange property, other binding mechanisms do exist. Chen et al. [131] suggested that apart from ion exchange, LDHs are able to bind $\mathrm{Cl}^{-}$ion following a mechanism of dissolution and recrystallisation, similar in behavior to AFm phases in concrete. The authors concluded that the ion exchange mechanism is the major contributor but it is hard to distinguish between these mechanisms in cementitious environment. The selectivity series were demonstrated to be $\mathrm{Cl}^{-}>\mathrm{OH}^{-}>\mathrm{NO}_{3}{ }^{-}$. Surface adsorption of ions on LDH surface has also been reported as an uptake mechanism for LDHs. Ke et al. [83] concluded that for hydrotalcite phases in concrete, which also belong to the LDH family, surface adsorption of anions could contribute to $90 \%$ uptake capacity and the rest was attributed to ion exchange.

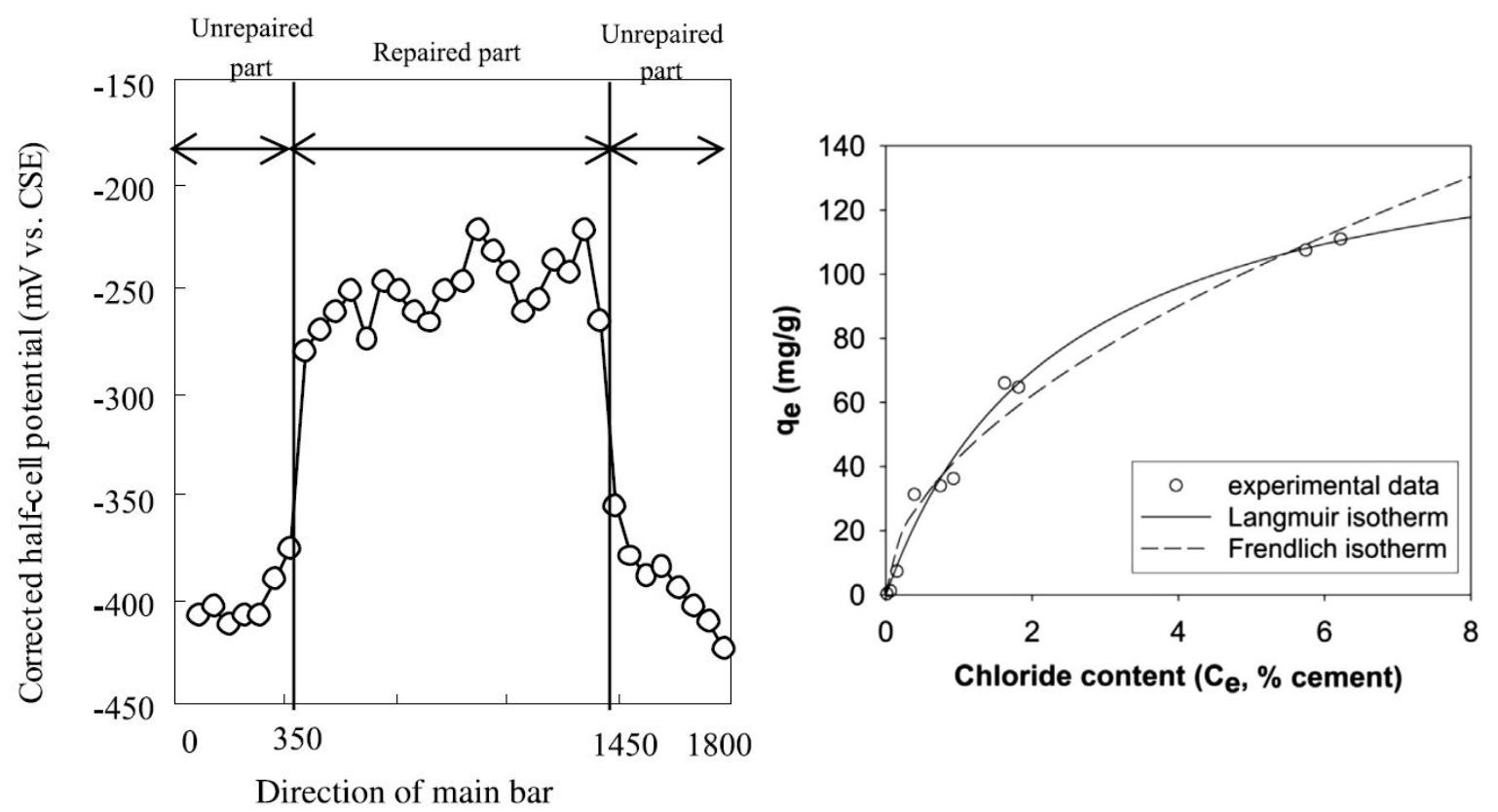

Figure 7. (Left) Figure shows steel with protective potential in the repaired part containing LDH with corrosion inhibitor (reprinted from [133] with permission from Elsevier). (Right) Experimental and fitted isotherms, both Langmuir and Freundlich for chloride uptake by LDH in cement paste (reprinted from [82] with permission from Elsevier).

One of the best real life tests on the use of LDHs in concrete structural members was carried out by Tatematsu et al. [133]. In their study, a concrete slab was used as a test specimen. A central portion of the slab was retrofitted with a reinforcement cover made of mortar with $\mathrm{Ca}-\mathrm{Al}-\mathrm{NO}_{2}$ as additive. They applied LDH as a $1 \mathrm{~mm}$ coat on rebars and then added LDH with mortar to form a $15 \mathrm{~mm}$ cover on top. Other parts of the specimen did not contain additive. The specimen was left in an exposure site for seven years. After seven years, the regions with $\mathrm{Ca}-\mathrm{Al}-\mathrm{NO}_{2}$ showed no signs of corrosion and more positive potentials whereas the surrounding regions were corroding as shown in Figure 7 
(left). Secondary reinforcement was also affected in the non-protected areas. The authors observed a macro-cell on the interface of protected and non-protected areas.

As mentioned previously, AFm phases in concrete also belong to LDH family and are responsible for the majority of the chloride binding $[49,51,135,136]$. The exchange mechanism is mostly believed to be ion exchange $[135,137]$. AFm phases just like synthetic LDHs lead to the formation of Friedel's salt and Kuzel's salt upon exposure to chloride [53,138]. The conversion of Hydroxy-AFm to Friedel's salt upon exposure to $\mathrm{NaCl}$ was stated to be a dominating chloride uptake mechanism by Jones et al. [139]. The $\mathrm{Cl}^{-}$uptake was observed to be followed by a delivery of $\mathrm{OH}^{-}$ion from AFm phases [140]. Hirao et al. [141] experiments on chloride uptake reveled a Freundlich type isotherm for chloride uptake, signifying that uptake capacity would improve as the external concentration increases. It can therefore be concluded that AFm phases in general contribute considerably to the inherent chloride binding capacity of concrete via ion exchange mechanism [142].

The dual benefit of self-protection of reinforced concrete can be achieved by the capture of $\mathrm{Cl}^{-}$ ion and simultaneous release of a corrosion inhibiting ion. LDHs can be easily loaded with corrosion inhibiting ions. The use of $\mathrm{NO}_{2}{ }^{-}$as a corrosion inhibitor has been well documented $[143,144]$ and also $\mathrm{NO}_{2}{ }^{-}$can be easily incorporated into LDH. However, it is important to note that the inhibitive action takes place only at the steel-concrete interface. The nitrite ions released in the bulk will have to transport themselves to the steel-concrete interface. On the other hand, LDH loaded with inhibiting ions can also be applied as a cement slurry coating on the rebar surface prior to embedment. Yang et al. [145], applied a coating of $20 \mathrm{wt} . \% \mathrm{LDH}$ on the reinforcing steel and reported an extended time regarding depassivation of steel. The combined role of chloride capture from the pore solution and inhibitor delivery can be represented as

$$
\mathrm{LDH} \cdots \text { Inhibitor }^{-}+\underset{\text { (Pore solution) }}{\mathrm{Cl}^{-}} \longrightarrow \mathrm{LDH}^{-} \cdot \mathrm{Cl}^{-}+\underset{\text { (Pore solution) }}{\text { Inhitor }^{-}}
$$

Use of $\mathrm{NO}_{2}{ }^{-}$ion in corrosion inhibition was previously tested by Dry [146] who used $\mathrm{Ca}\left(\mathrm{NO}_{2}\right)$ in concrete and reported a delay in corrosion as compared to control samples. Gomes et at. [25] used $\mathrm{LDH}$ loaded with $\mathrm{NO}_{2}{ }^{-}$ion with the aim of capturing $\mathrm{Cl}^{-}$ion and releasing $\mathrm{NO}_{2}{ }^{-}$ion and reported positive results.

Many authors $[25,100]$ have conducted natural diffusion test on concrete with added LDH in order to ascertain the enhanced chloride capture in such mixes. Yang et al. [100] conducted a rapid chloride migration tests on concrete with and without LDH. Two levels of LDH were used, namely $5 \%$ and $10 \%$ for two LDH types as shown in Figure 8. Samples with 5\% Mg-Al-PAB(p-aminobenzoate) demonstrated improved chloride resistance as compared to other dosages of LDH. The authors concluded that higher dosages could possible bind more chloride but at the same time also increase the porosity which has a counter effect on chloride transport in concrete.

Chloride diffusion test were also conducted by Qu et al. [97] with $0.5 \%, 1 \%$ and $2 \%$ by volume LDH dosage. They observed excellent chloride resistance of concrete for an optimum $1 \%$ LDH dosage. A $25 \%$ reduction of $\mathrm{D}_{R C M}$ (rapid chloride migration coefficient) was found for this dosage as compared to reference. The study also included natural diffusion test and demonstrated a $53 \%$ reduction in apparent diffusion coefficient. The authors explained their observations by the physical barrier properties of LDH particles acting as a filler material. This effect was complemented by chemical inhibition i.e., anion exchange property of LDH. The low dosages of up to $2 \%$ did not seem to cause any unnecessary porosity increase which is detrimental towards chloride resistance. Moreover, it was considered that smaller particles of LDH can improve the tortuosity of the cementitious matrix without actually influencing the porosity so much. 


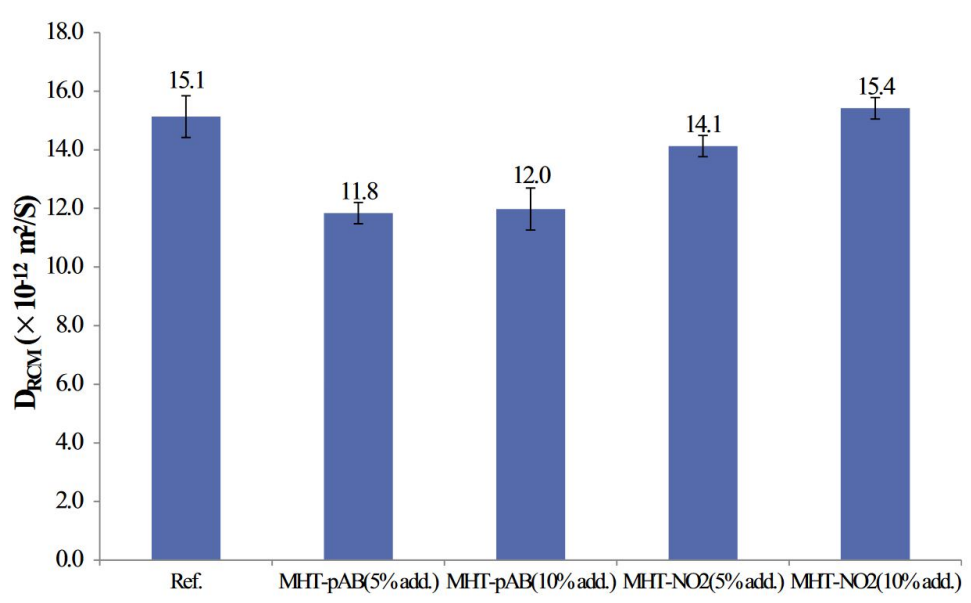

Figure 8. Chloride diffusion coefficients of mortar with 5\% and 10\% dosage of LDH. (Reprinted from [100], with permission from Elsevier).

\subsection{Role of Ldh in Carbonation Control}

It is well understood that the $\mathrm{CO}_{3}^{2-}$ form of $\mathrm{LDH}$ is the most stable because $\mathrm{LDH}$ has a preference to multivalent ions than monovalent ions [83]. Due to this very fact, LDH has also been used to improve the carbonation resistance of concrete $[147,148]$. In a recent work by Ma et al. [61], cement pastes with $2 \% \mathrm{Mg}$ based LDH showed reduced carbonation depth as compared with reference samples. They observed a 30\% reduction in carbonation depth at 42 day age. Similar findings were also reported by Shui et al. [132]. This highlights the positive benefits of employing LDH in carbonation control of structures.

The high affinity of LDH towards carbonate ions can have a negative impact on chloride binding capacity of $\mathrm{LDH}$. It is important to note that, if the $\mathrm{LDH}$ was previously exposed to $\mathrm{Cl}^{-}$ions and has bound $\mathrm{Cl}^{-}$ions, it might release these bound chlorides upon exposure to carbonates, since uptake of carbonate ions is preferred over chlorides [83]. Ke et al. [83] studied the chloride uptake by Mg-Al based and Strätlingite in carbonated and non-carbonated salt solutions. They reported that chloride uptake decreases as concentration of carbonate increased. Kayali et al. [58] concluded that carbonation is a risk because $\mathrm{Cl}^{-}$can be replaced with $\mathrm{CO}_{3}^{2-}$, thereby inducing risk of accelerated steel corrosion. However under certain circumstances, $\mathrm{LDH}$ can be decarbonated and exchanged with other anions. Iyi et al. [60] was able to exchange $\mathrm{Cl}^{-}$with $\mathrm{CO}_{3}^{2-}$ calling it the "decarbonation" of $\mathrm{LDH}$ under high concentrations of externally present $\mathrm{Cl}^{-}$. The study was extended to other anions as well but it was observed that only small ions such as $\mathrm{Cl}^{-}$and $\mathrm{Br}^{-}$are able to exchange themselves with $\mathrm{CO}_{3}^{2-}$. Much less or insignificant exchange was observed for larger anions such as $\mathrm{NO}_{3}{ }^{-}$and $\mathrm{ClO}_{4}^{-}$. The anion size effect was also demonstrated by Miyata [126]. 
Table 2. Reported LDH types and their application in the literature together with preparation and experimental details. Abbreviations are mentioned in the end of the text. SS: Salt solution; PS: Pore solution; CP: Cement Paste; M: Mortar; C: Concrete

\begin{tabular}{|c|c|c|c|c|c|c|c|c|c|c|}
\hline \multirow[t]{2}{*}{ LDH } & \multicolumn{5}{|c|}{ Experiments Conducted in } & \multirow[t]{2}{*}{ Preparation Method } & \multicolumn{2}{|c|}{ Dosage $^{+}$} & \multirow[t]{2}{*}{ Application } & \multirow[t]{2}{*}{ Year / Ref. } \\
\hline & SS & PS & $\mathrm{CP}$ & $\mathbf{M}$ & $\mathrm{C}$ & & SS / PS & $\mathrm{CP} / \mathrm{M} / \mathrm{C}$ & & \\
\hline $\mathrm{CaAl} \mathrm{NO} 2$ & - & - & $\checkmark$ & $\checkmark$ & - & - & - & 0.2 wt. $\%$ & $\mathrm{Cl}^{-}$uptake \& Corr. inhibition & $2003 /[133]$ \\
\hline $\mathrm{MgAlNO}$ & $\checkmark$ & - & $\checkmark$ & - & - & - & $1 \mathrm{~g}: 10 \mathrm{~mL}$ & 1 wt. $\%$ & $\mathrm{Cl}^{-}$uptake & $2012 /[134]$ \\
\hline $\mathrm{MgAlCO}_{3}$ & $\checkmark$ & - & $\checkmark$ & - & - & - & $1 \mathrm{~g}: 10 \mathrm{~mL}$ & 1 wt. $\%$ & $\mathrm{Cl}^{-}$uptake & 2012 / [134] \\
\hline hydrotalcite & $\checkmark$ & - & - & - & - & calcination & $8-16 \mathrm{~g} / 80 \mathrm{~mL}$ & - & $\mathrm{Cl}^{-}$uptake & 2012 / [93] \\
\hline $\mathrm{MgAl} \mathrm{NO} 3$ & - & - & - & - & $\checkmark$ & - & - & $0.5-3$ wt. $\%$ & $\mathrm{Cl}^{-}$uptake & 2012 / [149] \\
\hline MgAl LDH & $\checkmark$ & - & $\checkmark$ & - & - & calcination & - & 8.5 wt. $\%$ & $\mathrm{Cl}^{-}$uptake & $2014 /[82]$ \\
\hline $\mathrm{MgAlCO}_{3}$ & - & - & $\checkmark$ & - & $\checkmark$ & - & - & $1-2$ wt. $\%$ & $\mathrm{Cl}^{-} / \mathrm{CO}_{3}^{2-}$ uptake \& Pore ref. & $2013 / 99]$ \\
\hline CaAl-pAB & - & $\checkmark$ & - & - & - & Ion-exchange & $0.5 \mathrm{~g} / 10 \mathrm{~mL}$ & - & $\mathrm{Cl}^{-}$uptake & 2014 / [150] \\
\hline $\mathrm{CaAl} \mathrm{NO}_{3}$ & - & $\checkmark$ & - & - & - & co-precipitation & $0.5 \mathrm{~g} / 10 \mathrm{~mL}$ & - & $\mathrm{Cl}^{-}$uptake & 2014 / [150] \\
\hline $\mathrm{CaAl} \mathrm{NO} 3$ & $\checkmark$ & $\checkmark$ & $\checkmark$ & - & - & co-precipitation & $1 \mathrm{~g} / 100 \mathrm{~mL}$ & 8.5 wt. $\%$ & $\mathrm{Cl}^{-}$uptake & $2015 /[131]$ \\
\hline MgAl-pAB & - & - & - & $\checkmark$ & - & calcination-rehydration [151] & - & 5-10 wt.\% & $\mathrm{Cl}^{-}$uptake & $2015 /[100]$ \\
\hline $\mathrm{MgAl}-\mathrm{NO}_{2}$ & - & - & - & $\checkmark$ & - & calcination-rehydration [151] & - & 5-10 wt.\% & $\mathrm{Cl}^{-}$uptake & 2015 / [100] \\
\hline MgAl LDH & - & - & - & $\checkmark$ & - & calcination & - & 1 wt.\% & $\mathrm{Cl}^{-}$uptake \& bond stress & $2015 /[101]$ \\
\hline Strätlingite & - & $\checkmark$ & - & - & - & [152] & $0.4 \mathrm{~g} / 40 \mathrm{~g}$ & - & $\mathrm{Cl}^{-} / \mathrm{CO}_{3}^{2-}$ uptake & 2017 / [83] \\
\hline MgAl LDH & - & $\checkmark$ & - & - & - & calcination & $0.4 \mathrm{~g} / 40 \mathrm{~g}$ & - & $\mathrm{Cl}^{-} / \mathrm{CO}_{3}^{2-}$ uptake & 2017 / [83] \\
\hline $\mathrm{MgAl} \mathrm{NO}_{3}$ & - & $\checkmark$ & $\checkmark$ & $\checkmark$ & - & calcination-rehydration & $0.5 \mathrm{~g} / 20 \mathrm{~mL}$ & $0-10 \%(\mathrm{M}), 20$ wt. $\%(\mathrm{CP})$ & $\mathrm{Cl}^{-}$-uptake \& Corr. inhibition & $2017 /[145]$ \\
\hline MgAl-pAB & - & $\checkmark$ & $\checkmark$ & $\checkmark$ & - & calcination-rehydration & $0.5 \mathrm{~g} / 20 \mathrm{~mL}$ & $0-10 \%(\mathrm{M}), 20$ wt. $\%(\mathrm{CP})$ & $\mathrm{Cl}^{-}$-uptake \& Corr. inhibition & $2017 /[145]$ \\
\hline $\mathrm{CaAl} \mathrm{NO}$ & - & - & - & $\checkmark$ & - & co-precipitation & - & $0.5-2$ vol. $\%$ & $\mathrm{Cl}^{-}$uptake & 2018 / [97] \\
\hline $\mathrm{MgAlCO}_{3}$ & - & - & - & - & $\checkmark$ & calcination, other [130] & - & 2 wt. $\%$ & $\mathrm{CO}_{3}^{2-}$ uptake & $2018 /[130]$ \\
\hline MgAl LDH & - & - & - & - & $\checkmark$ & calcination, other [132] & - & $2-4$ wt. $\%$ & $\mathrm{CO}_{3}^{2-}$ uptake & $2018 /[132]$ \\
\hline $\mathrm{MgAl} \mathrm{NO}_{2}$ & - & $\checkmark$ & - & - & - & Ion-exchange & $1 \mathrm{~g} / 10 \mathrm{~mL}, 1-2 \mathrm{wt} . \%$ & - & Cl-uptake \& Corr. inhibition & $2018 /[153]$ \\
\hline $\mathrm{MgAl} \mathrm{NO}$ & - & $\checkmark$ & - & - & - & co-precipitation & $1 \mathrm{~g} / 10 \mathrm{~mL}, 1-2 \mathrm{wt} . \%$ & - & $\mathrm{Cl}^{-}$uptake & $2018 /[153]$ \\
\hline MgAl LDH & - & - & $\checkmark$ & - & - & calcination & - & $1-2$ wt. $\%$ & $\mathrm{Cl}^{-}$uptake & $2018 /[104]$ \\
\hline $\mathrm{CaAl} \mathrm{LDH}$ & $\checkmark$ & - & - & - & $\checkmark$ & co-precipitation & $50 \mathrm{~g} / \mathrm{L}$ & 10 wt. $\%$ & $\mathrm{Cl}^{-}$uptake & $2019 /[154]$ \\
\hline $\mathrm{ZnAl} \mathrm{NO} / \mathrm{NO}_{3}$ & $\checkmark$ & $\checkmark$ & $\checkmark$ & - & - & co-precipitation & $1 \mathrm{~g} / 50 \mathrm{~mL}$ & $2-5$ wt. $\%$ & $\mathrm{Cl}^{-}$uptake \& Corr. inhibition & $2019 /[24,25]$ \\
\hline $\mathrm{MgAlCO} 3$ & - & - & - & - & $\checkmark$ & calcination & - & 2 wt. $\%$ & $\mathrm{CO}_{3}^{2-}$ uptake & 2019 / [61] \\
\hline
\end{tabular}

${ }^{+}$In mentioning the dosage in cement paste, mortars and concrete, no distinction has been made for LDH added as $\%$ of binder content or $\%$ of binder replacement or $\%$ of total cementitious materials. 


\section{Conclusions}

In this study a review on the applications of LDH in concrete is presented. The main advantage of using LDH in concrete is to improve the chloride and carbonation resistance of concrete. This can consequently extend the service life of concrete structures exposed to corrosive environments. In this aspect, this review presents many recent studies reporting on the application of LDH not only in pore solutions but also in concretes, mortars and pastes. The review also showcases that even though LDH addition is primarily aimed to improve chloride/carbonation resistance, its addition can also affect hydration, strength, microstructure and other properties of concrete. Additionally, recommendations on LDH dosage are presented. In general, this review should aid scientists and engineers to develop a basic understanding on the use of $\mathrm{LDH}$ as an engineering material and help in the design of experiments and be able to foresee main results. Depending of the type of LDH as starting material, quantitative and qualitative effects on desired property as well as associated properties of concrete are presented, trends are identified and selected results are discussed. A compilation of focused results are presented in text as well as in tables, highlighting the benefits of LDH as well as details of the experiments and main results.

The ion exchange property of LDH has been widely exploited in concrete technology with a majority of applications aimed towards increasing the chloride and carbonation resistance of concrete. Although the underlying mechanics for these applications are well researched and thoroughly discussed in this text, many other mechanisms are still not fully clear and vary with the type of LDH, such as, the effect of increase of compressive strength and flexural strength upon addition of LDH, as well as acceleration of hydration kinetics. Moreover, there is no general consensus on the optimum dosage of LDH in concrete, although a $2 \%$ dosage has been identified as the threshold of LDH addition from the presented literature. A higher dosage can cause agglomeration of particles and have a profound effect on key properties such as chloride durability and compressive strength.

Despite the recent advances in the application of LDH in concrete technology, many issues stay unresolved and need further understanding. Firstly, the stability of LDH particles inside concrete is not well understood and needs more research in the future. Higher $\mathrm{pH}$ of fresh concrete can potentially cause partial dissolution of LDH particles which can in turn reduce their functionality. Apart from that, particle size is a very important parameter as finer particles exhibit more surface area than coarse particles. It has been reported that particle size effects LDH functionality as well as some vital concrete properties. Very few studies have reported on these issues and more research is required in this area. Additionally, one important factor is the economic aspect of using LDH as a concrete additive and not much information is available on the cost of LDH and its carbon footprint. These two factors are very important for acceptance of LDH in the concrete infrastructure market. Dismantling buildings made with nano-particles can be dangerous as there is the chance that these nano particles might be released in the environment. Therefore, proper guidelines should be made available to building engineers and these buildings should be classified for easy recognition in the distant future. More research must be conducted on the interaction of humans against long term exposure to LDH. All these points need more efforts and extensive research.

However, the authors strongly believe that LDH due to its unique chemistry, versatile combinations, facile preparation and ease of incorporation into concrete, will be used more in the future to produce smart concrete structures. To make LDH a promising concrete additive, more research should be focused towards their application in concrete. One of the biggest foreseeable benefit of using LDH in concrete is the enhanced chloride/carbonate binding effect, although other notable benefits have been presented. This class of additive can result in smart structures which can potentially show extended service life and can directly result in a substantial economic benefit in the global infrastructure market.

Author Contributions: Z.M.M. and M.L.Z. proposed the concept behind the study. Z.M.M. and A.B. did the literature study and co-wrote the script. A.B., M.L.Z. and D.H. revised the script, provided critical comments and supervised the work. All authors have read and agreed to the published version of the manuscript. 
Funding: This research has received funding from the European Union's Horizon 2020 research and innovation program under grant agreement No: 685445 (LORCENIS-Long Lasting Reinforced Concrete for Energy infrastructure under Severe Operating Conditions).

Acknowledgments: Ralf T. Schmitt, Museum für Naturkunde Berlin.

Conflicts of Interest: The authors declare no conflicts of interest.

\section{Abbreviations}

The following abbreviations are used in this manuscript:

LDH Layered Double Hydroxide

CSE Copper sulphate electrode

pAB P-aminobenzoate

$\mathrm{C}_{3} \mathrm{~A}$ tricalcium aluminate

$\mathrm{C}_{4} \mathrm{AF}$ tetracalcium alumino-ferrite

AFm aluminate monosulphate

$\mathrm{CSH}$ calcium silicate hydrate

\section{References}

1. DESA; UN. World Population Prospects 2019: Highlights; United Nations Department for Economic and Social Affairs: New York, NY, USA, 2019.

2. Mehta, P.K. Greening of the concrete industry for sustainable development. Concr. Int. 2002, 24, $23-28$.

3. Huntzinger, D.N.; Eatmon, T.D. A life-cycle assessment of Portland cement manufacturing: Comparing the traditional process with alternative technologies. J. Clean. Prod. 2009, 17, 668-675. [CrossRef]

4. Uwasu, M.; Hara, K.; Yabar, H. World cement production and environmental implications. Environ. Dev. 2014, 10, 36-47. [CrossRef]

5. Kim, Y.; Worrell, E. $\mathrm{CO}_{2}$ emission trends in the cement industry: An international comparison. Mitig. Adapt. Strateg. Glob. Chang. 2002, 7, 115-133. [CrossRef]

6. Chen, C.; Habert, G.; Bouzidi, Y.; Jullien, A. Environmental impact of cement production: Detail of the different processes and cement plant variability evaluation. J. Clean. Prod. 2010, 18, 478-485. [CrossRef]

7. Tuutti, K. Corrosion of Steel in Concrete - (Technical Report); Cement-och Betonginst CBI Sweden: Stockholm, Sweden, 1982.

8. Bertolini, L.; Elsener, B.; Pedeferri, P.; Redaelli, E.; Polder, R. Corrosion of Steel in Concrete; Wiley-Vch.: Weinheim, Germany, 2013; Volume 392.

9. Broomfield, J.P. Corrosion of Steel in Concrete: Understanding, Investigation and Repair; CRC Press: Boca Raton, FL, USA, 2003.

10. Poursaee, A. Corrosion of steel in concrete structures. In Corrosion of Steel in Concrete Structures; Elsevier: Amsterdam, The Netherlands, 2016; pp. 19-33.

11. Raupach, M.; Elsener, B.; Polder, R.; Mietz, J. Corrosion of Reinforcement in Concrete: Monitoring, Prevention and Rehabilitation Techniques; Woodhead Publishing: Sawston, UK, 2014; Volume 38.

12. Lewis, D.; Copenhagen, W. Corrosion of reinforcing steel in concrete in marine atmospheres. Corrosion 1959, 15, 60-66. [CrossRef]

13. Hausmann, D. Steel corrosion in concrete-How does it occur? Mater. Prot. 1967, 6, 19-23.

14. Page, C. Mechanism of corrosion protection in reinforced concrete marine structures. Nature 1975, $258,514$. [CrossRef]

15. Cai, H.; Liu, X. Freeze-thaw durability of concrete: Ice formation process in pores. Cem. Concr. Res. 1998, 28, 1281-1287. [CrossRef]

16. Berto, L.; Saetta, A.; Talledo, D. Constitutive model of concrete damaged by freeze-thaw action for evaluation of structural performance of RC elements. Constr. Build. Mater. 2015, 98, 559-569. [CrossRef]

17. Huovinen, S. Abrasion of Concrete by Ice in Arctic Sea Structures; Technical Research Centre of Finland: Espoo, Finland, 1990.

18. Jacobsen, S.; Scherer, G.W.; Schulson, E.M. Concrete-ice abrasion mechanics. Cem. Concr. Res. 2015, 73, 79-95. [CrossRef] 
19. Ryan, A. Ice Wear and Abrasion of Marine Concrete: Design of Experimental Apparatus and Procedures. Ph.D. Thesis, Memorial University of Newfoundland, St. John's, NL, Canada, 2018.

20. Marchand, J.; Odler, I.; Skalny, J.P. Sulfate Attack on Concrete; CRC Press: Boca Raton, FL, USA, 2001.

21. Attiogbe, E.K.; Rizkalla, S.H. Response of concrete to sulfuric acid attack. ACI Mater. J. 1988, 85, 481-488.

22. Glass, G.; Buenfeld, N. Chloride-induced corrosion of steel in concrete. Prog. Struct. Eng. Mater. 2000, 2, 448-458. [CrossRef]

23. Angst, U.M. Challenges and opportunities in corrosion of steel in concrete. Mater. Struct. 2018, 51, 4. [CrossRef]

24. Gomes, C.; Mir, Z.; Sampaio, R.S.; Bastos, A.; Maia, F.; Rocha, C.; Tedim, J.; Ferreira, M. Effect of Layered Double Hydroxides on the Performance and Service Life of Reinforced Concrete. In Durable Concrete for Infrastructure under Severe Conditions Smart Admixtures, Self-Responsiveness and Nano-Additions Proceedings 10-11 September 2019; Ghent. Ghent University, Ghent, Belgium, 2019; pp. 51-54.

25. Gomes, C.; Mir, Z.; Sampaio, R.S.; Bastos, A.; Tedim, J.; Maia, F.; Rocha, C.; Ferreira, M. On the use of ZnAl layered double hydroxide (LDH) to extend the service life of reinforced concrete. Front. Mater. (in review).

26. Raki, L.; Beaudoin, J.; Mitchell, L. Layered double hydroxide-like materials: Nanocomposites for use in concrete. Cem. Concr. Res. 2004, 34, 1717-1724. [CrossRef]

27. Yang, Z.; Fischer, H.; Polder, R. Modified hydrotalcites as a new emerging class of smart additive of reinforced concrete for anticorrosion applications: A literature review. Mater. Corros. 2013, 64, 1066-1074. [CrossRef]

28. Yang, Z.; Fischer, H.; Polder, R. Possibilities for improving corrosion protection of reinforced concrete by modified hydrotalcites-a literature review. In Advances in Modeling Concrete Service Life; RILEM Bookseries, vol 3. Springer: Dordrecht, The Netherlands, 2012; pp. 95-105.

29. USGS. Cement: 2007 Minerals Yearbook - US. Geological Survey; USGS: Reston, VA, USA, 2010.

30. Gagg, C.R. Cement and concrete as an engineering material: An historic appraisal and case study analysis. Eng. Fail. Anal. 2014, 40, 114-140. [CrossRef]

31. Poursaee, A.; Hansson, C. Reinforcing steel passivation in mortar and pore solution. Cem. Concr. Res. 2007, 37, 1127-1133. [CrossRef]

32. Ghods, P.; Isgor, O.; McRae, G.; Li, J.; Gu, G. Microscopic investigation of mill scale and its proposed effect on the variability of chloride-induced depassivation of carbon steel rebar. Corros. Sci. 2011, 53, 946-954. [CrossRef]

33. Andrade, C.; Merino, P.; Novoa, X.; Perez, M.; Soler, L. Passivation of reinforcing steel in concrete. In Materials Science Forum; Trans Tech Publications Ltd: Stafa-Zurich, Switzerland, 1995; Volume 192, pp. 891-898.

34. Saremi, M.; Mahallati, E. A study on chloride-induced depassivation of mild steel in simulated concrete pore solution. Cem. Concr. Res. 2002, 32, 1915-1921. [CrossRef]

35. Ghods, P.; Isgor, O.; McRae, G.; Miller, T. The effect of concrete pore solution composition on the quality of passive oxide films on black steel reinforcement. Cem. Concr. Compos. 2009, 31, 2-11. [CrossRef]

36. Ghods, P.; Isgor, O.; Carpenter, G.; Li, J.; McRae, G.; Gu, G. Nano-scale study of passive films and chloride-induced depassivation of carbon steel rebar in simulated concrete pore solutions using FIB/TEM. Cem. Concr. Res. 2013, 47, 55-68. [CrossRef]

37. Lian, C.; Zhuge, Y.; Beecham, S. The relationship between porosity and strength for porous concrete. Constr. Build. Mater. 2011, 25, 4294-4298. [CrossRef]

38. Angst, U.M.; Geiker, M.R.; Michel, A.; Gehlen, C.; Wong, H.; Isgor, O.B.; Elsener, B.; Hansson, C.M.; François, R.; Hornbostel, K.; et al. The steel-concrete interface. Mater. Struct. 2017, 50, 143. [CrossRef]

39. Alonso, C.; Andrade, C.; Castellote, M.; Castro, P. Chloride threshold values to depassivate reinforcing bars embedded in a standardized OPC mortar. Cem. Concr. Res. 2000, 30, 1047-1055. [CrossRef]

40. Angst, U.; Elsener, B.; Larsen, C.K.; Vennesland, Ø. Critical chloride content in reinforced concrete-A review. Cem. Concr. Res. 2009, 39, 1122-1138. [CrossRef]

41. Suda, K.; Misra, S.; Motohashi, K. Corrosion products of reinforcing bars embedded in concrete. Corros. Sci. 1993, 35, 1543-1549. [CrossRef]

42. Molina, F.; Alonso, C.; Andrade, C. Cover cracking as a function of rebar corrosion: Part 2-Numerical model. Mater. Struct. 1993, 26, 532-548. [CrossRef]

43. Sola, E.; Ožbolt, J.; Balabanić, G.; Mir, Z. Experimental and numerical study of accelerated corrosion of steel reinforcement in concrete: Transport of corrosion products. Cem. Concr. Res. 2019, 120, 119-131. [CrossRef] 
44. Sola, E. Experimental and Numerical Study of Chloride Induced Corrosion in Reinforced Concrete. Ph.D. Thesis, University of Stuttgart, Stuttgart, Germany, 2017.

45. Ožbolt, J.; Oršanić, F.; Balabanić, G. Modeling influence of hysteretic moisture behavior on distribution of chlorides in concrete. Cem. Concr. Compos. 2016, 67, 73-84. [CrossRef]

46. Yuan, Q.; Shi, C.; De Schutter, G.; Audenaert, K.; Deng, D. Chloride binding of cement-based materials subjected to external chloride environment-a review. Constr. Build. Mater. 2009, 23, 1-13. [CrossRef]

47. Arya, C.; Buenfeld, N.; Newman, J. Factors influencing chloride-binding in concrete. Cem. Concr. Res. 1990, 20, 291-300. [CrossRef]

48. Page, C.L. Initiation of chloride-induced corrosion of steel in concrete: Role of the interfacial zone. Mater. Corros. 2009, 60, 586-592. [CrossRef]

49. Justnes, H. A review of chloride binding in cementitious systems. Nord. Concr. Res. Publ. 1998, 21, 48-63.

50. Neville, A. Chloride attack of reinforced concrete: An overview. Mater. Struct. 1995, 28, 63. [CrossRef]

51. Florea, M.; Brouwers, H. Chloride binding related to hydration products: Part I: Ordinary Portland Cement. Cem. Concr. Res. 2012, 42, 282-290. [CrossRef]

52. Suryavanshi, A.; Scantlebury, J.; Lyon, S. Mechanism of Friedel's salt formation in cements rich in tri-calcium aluminate. Cem. Concr. Res. 1996, 26, 717-727. [CrossRef]

53. Zibara, H. Binding of External Chlorides by Cement Pastes. Ph.D. Thesis, National Library of Canada= Bibliothèque nationale du Canada, Ottawa, ON, Canada, 2001.

54. Traetteberg, A. The mechanism of chloride penetration in concrete. SINTEF Rep. STF65 A 1977, 77070, 1977.

55. Luping, T.; Nilsson, L.O. Chloride binding capacity and binding isotherms of OPC pastes and mortars. Cem. Concr. Res. 1993, 23, 247-253. [CrossRef]

56. Al-Hussaini, M.; Sangha, C.; Plunkett, B.; Walden, P. The effect of chloride ion source on the free chloride ion percentages in OPC mortars. Cem. Concr. Res. 1990, 20, 739-745. [CrossRef]

57. Juenger, M.C.; Siddique, R. Recent advances in understanding the role of supplementary cementitious materials in concrete. Cem. Concr. Res. 2015, 78, 71-80. [CrossRef]

58. Kayali, O.; Ahmed, M.; Khan, M. Friedel's salt and hydrotalcite-layered double hydroxides and the protection against chloride induced corrosion. Civ. Envir. Res 2013, 5, 111-117.

59. Dhir, R.; El-Mohr, M.; Dyer, T. Chloride binding in GGBS concrete. Cem. Concr. Res. 1996, 26, 1767-1773. [CrossRef]

60. Iyi, N.; Okamoto, K.; Kaneko, Y.; Matsumoto, T. Effects of anion species on deintercalation of carbonate ions from hydrotalcite-like compounds. Chem. Lett. 2005, 34, 932-933. [CrossRef]

61. Ma, J.; Duan, P.; Ren, D.; Zhou, W. Effects of layered double hydroxides incorporation on carbonation resistance of cementitious materials. J. Mater. Res. Technol. 2019, 8, 292-298. [CrossRef]

62. Alcantara, A.; Aranda, P.; Darder, M.; Ruiz-Hitzky, E. Bionanocomposites based on alginate-zein/layered double hydroxide materials as drug delivery systems. J. Mater. Chem. 2010, 20, 9495-9504. [CrossRef]

63. Bejoy, N. Hydrotalcite. Resonance 2001, 6, 57-61. [CrossRef]

64. Kwak, S.Y.; Jeong, Y.J.; Park, J.S.; Choy, J.H. Bio-LDH nanohybrid for gene therapy. Solid State Ionics 2002, 151, 229-234. [CrossRef]

65. Cai, P.; Zheng, H.; Wang, C.; Ma, H.; Hu, J.; Pu, Y.; Liang, P. Competitive adsorption characteristics of fluoride and phosphate on calcined Mg-Al-CO3 layered double hydroxides. J. Hazard. Mater. 2012, 213, 100-108. [CrossRef]

66. Kameda, T.; Takeuchi, H.; Yoshioka, T. Uptake of heavy metal ions from aqueous solution using Mg-Al layered double hydroxides intercalated with citrate, malate, and tartrate. Sep. Purif. Technol. 2008, 62, 330-336. [CrossRef]

67. Lv, L.; He, J.; Wei, M.; Evans, D.; Duan, X. Uptake of chloride ion from aqueous solution by calcined layered double hydroxides: Equilibrium and kinetic studies. Water Res. 2006, 40, 735-743. [CrossRef] [PubMed]

68. Douglas, G.; Wendling, L.; Pleysier, R.; Trefry, M. Hydrotalcite formation for contaminant removal from Ranger mine process water. Mine Water Environ. 2010, 29, 108-115. [CrossRef]

69. Alvarez, D.; Collazo, A.; Hernández, M.; Nóvoa, X.R.; Pérez, C. Corrosion protective properties of hydrotalcites doped hybrid sol-gel coatings on aluminium substrates. In Materials Science Forum; Trans Tech Publications Ltd: Stafa-Zurich, Switzerland, 2010; Volume 636, pp. 996-1003.

70. Wajima, T.; Shimizu, T.; Ikegami, Y. New simple process of making agricultural cultivation solution from seawater. Bull. Soc. Sea Water Sci. Jpn. 2006, 60, 201-202. 
71. Mohapatra, L.; Parida, K. Zn-Cr layered double hydroxide: Visible light responsive photocatalyst for photocatalytic degradation of organic pollutants. Sep. Purif. Technol. 2012, 91, 73-80. [CrossRef]

72. Peng, C.; Yu, J.; Zhao, Z.; Dai, J.; Fu, J.; Zhao, M.; Wang, W. Synthesis and properties of a clean and sustainable deicing additive for asphalt mixture. PLoS ONE 2015, 10, e0115721. [CrossRef] [PubMed]

73. Rives, V. Layered Double Hydroxides: Present and Future; Nova Publishers: Hauppauge, NY, USA, 2001.

74. Duan, X.; Evans, D.G. Layered Double Hydroxides; Springer Science \& Business Media: Berlin/Heidelberg, Germany, 2006; Volume 119.

75. Bontchev, R.P.; Liu, S.; Krumhansl, J.L.; Voigt, J.; Nenoff, T.M. Synthesis, characterization, and ion exchange properties of hydrotalcite $\mathrm{Mg}_{6} \mathrm{Al}_{2}(\mathrm{OH})_{16}(\mathrm{~A})_{x}\left(\mathrm{~A}^{\prime}\right)_{2-x} .4 \mathrm{H}_{2} \mathrm{O}\left(\mathrm{A}, \mathrm{A}^{\prime}=\mathrm{Cl}^{-}, \mathrm{Br}^{-}, \mathrm{I}^{-}\right.$, and $\left.\mathrm{NO}_{3}^{-}, 2 \geqslant \mathrm{x} \geqslant 0\right)$ derivatives. Chem. Mater. 2003, 15, 3669-3675. [CrossRef]

76. Newman, S.P.; Jones, W. Comparative study of some layered hydroxide salts containing exchangeable interlayer anions. J. Solid State Chem. 1999, 148, 26-40. [CrossRef]

77. Newman, S.P.; Jones, W. Synthesis, characterization and applications of layered double hydroxides containing organic guests. New J. Chem. 1998, 22, 105-115. [CrossRef]

78. Lv, L.; Sun, P.; Gu, Z.; Du, H.; Pang, X.; Tao, X.; Xu, R.; Xu, L. Removal of chloride ion from aqueous solution by ZnAl-NO3 layered double hydroxides as anion-exchanger. J. Hazard. Mater. 2009, 161, 1444-1449. [CrossRef]

79. de Sá, F.P.; Cunha, B.N.; Nunes, L.M. Effect of $\mathrm{pH}$ on the adsorption of Sunset Yellow FCF food dye into a layered double hydroxide (CaAl-LDH-NO3). Chem. Eng. J. 2013, 215, 122-127. [CrossRef]

80. He, J.; Wei, M.; Li, B.; Kang, Y.; Evans, D.G.; Duan, X. Preparation of layered double hydroxides. In Layered Double Hydroxides; Springer-Verlag: Berlin, Heidelberg, Germany, 2006; pp. 89-119.

81. Zuo, J.; Wu, B.; Luo, C.; Dong, B.; Xing, F. Preparation of MgAl layered double hydroxides intercalated with nitrite ions and corrosion protection of steel bars in simulated carbonated concrete pore solution. Corros. Sci. 2019, 152, 120-129. [CrossRef]

82. Yoon, S.; Moon, J.; Bae, S.; Duan, X.; Giannelis, E.P.; Monteiro, P.M. Chloride adsorption by calcined layered double hydroxides in hardened Portland cement paste. Mater. Chem. Phys. 2014, 145, 376-386. [CrossRef]

83. Ke, X.; Bernal, S.A.; Provis, J.L. Uptake of chloride and carbonate by Mg-Al and Ca-Al layered double hydroxides in simulated pore solutions of alkali-activated slag cement. Cem. Concr. Res. 2017, 100, 1-13. [CrossRef]

84. Wong, F.; Buchheit, R. Utilizing the structural memory effect of layered double hydroxides for sensing water uptake in organic coatings. Prog. Org. Coatings 2004, 51, 91-102. [CrossRef]

85. Wei, J.; Gao, Z.; Song, Y.; Yang, W.; Wang, J.; Li, Z.; Mann, T.; Zhang, M.; Liu, L. Solvothermal synthesis of Li-Al layered double hydroxides and their electrochemical performance. Mater. Chem. Phys. 2013, 139, 395-402. [CrossRef]

86. Bergaya, F.; Lagaly, G. Handbook of Clay Science; Elsevier: Amsterdam, The Netherlands, 2013.

87. Hochstetter, C. Untersuchung über die Zusammensetzung einiger Mineralien. J. Für Prakt. Chem. 1842, 27, 375-378. [CrossRef]

88. Matschei, T.; Lothenbach, B.; Glasser, F. The AFm phase in Portland cement. Cem. Concr. Res. 2007, 37, 118-130. [CrossRef]

89. Renaudin, G.; Francois, M.; Evrard, O. Order and disorder in the lamellar hydrated tetracalcium monocarboaluminate compound. Cem. Concr. Res. 1999, 29, 63-69. [CrossRef]

90. Provis, J.L.; Bernal, S.A. Geopolymers and related alkali-activated materials. Annu. Rev. Mater. Res. 2014, 44, 299-327. [CrossRef]

91. Wang, S.D.; Scrivener, K.L. Hydration products of alkali activated slag cement. Cem. Concr. Res. 1995, 25, 561-571. [CrossRef]

92. Ke, X.; Bernal, S.A.; Provis, J.L. Chloride binding capacity of hydrotalcite in near-neutral and alkaline environments. In Proceedings of the 34thCementand Concrete Science Conference, University of Sheffield, Sheffield, UK, 14-17 September 2014.

93. Kayali, O.; Khan, M.; Ahmed, M.S. The role of hydrotalcite in chloride binding and corrosion protection in concretes with ground granulated blast furnace slag. Cem. Concr. Compos. 2012, 34, 936-945. [CrossRef]

94. Tedim, J.; Kuznetsova, A.; Salak, A.; Montemor, F.; Snihirova, D.; Pilz, M.; Zheludkevich, M.; Ferreira, M. $\mathrm{Zn}-\mathrm{Al}$ layered double hydroxides as chloride nanotraps in active protective coatings. Corros. Sci. 2012, 55, 1-4. [CrossRef] 
95. Forano, C.; Hibino, T.; Leroux, F.; Taviot-Guého, C. Chapter 13.1 layered double hydroxides in Handbook of Clay science. Dev. Clay Sci. 2006, 1, 1021-1095.

96. Kuang, Y.; Zhao, L.; Zhang, S.; Zhang, F.; Dong, M.; Xu, S. Morphologies, preparations and applications of layered double hydroxide micro-/nanostructures. Materials 2010, 3, 5220-5235. [CrossRef]

97. Qu, Z.; Yu, Q.; Brouwers, H. Relationship between the particle size and dosage of LDHs and concrete resistance against chloride ingress. Cem. Concr. Res. 2018, 105, 81-90. [CrossRef]

98. Xu, S.; Chen, Z.; Zhang, B.; Yu, J.; Zhang, F.; Evans, D.G. Facile preparation of pure CaAl-layered double hydroxides and their application as a hardening accelerator in concrete. Chem. Eng. J. 2009, 155, 881-885. [CrossRef]

99. Duan, P.; Chen, W.; Ma, J.; Shui, Z. Influence of layered double hydroxides on microstructure and carbonation resistance of sulphoaluminate cement concrete. Constr. Build. Mater. 2013, 48, 601-609. [CrossRef]

100. Yang, Z.; Fischer, H.; Polder, R. Laboratory investigation of the influence of two types of modified hydrotalcites on chloride ingress into cement mortar. Cem. Concr. Compos. 2015, 58, 105-113. [CrossRef]

101. Xiong, L.X.; Liu, C.J.; Yuan, X.W. Effects of calcined $\mathrm{Mg}-\mathrm{Al}-\mathrm{CO}_{3}$ layered double hydroxides on resistance of cement mortar to chloride erosion. Ind. J. Eng. and Mater. Sci. 2015, 22, 225-230.

102. Li, H.; Guan, X.; Yang, L.; Liu, S.; Zhang, J.; Guo, Y. Effects of LiAl-layered double hydroxides on early hydration of calcium sulphoaluminate cement paste. J. Wuhan Univ. Technol.-Mater. Sci. Ed. 2017, 32, 1101-1107. [CrossRef]

103. Wu, Y.; Duan, P.; Yan, C. Role of layered double hydroxides in setting, hydration degree, microstructure and compressive strength of cement paste. Appl. Clay Sci. 2018, 158, 123-131. [CrossRef]

104. Chen, Y.; Yu, R.; Wang, X.; Chen, J.; Shui, Z. Evaluation and optimization of Ultra-High Performance Concrete (UHPC) subjected to harsh ocean environment: Towards an application of Layered Double Hydroxides (LDHs). Constr. Build. Mater. 2018, 177, 51-62. [CrossRef]

105. Zou, D.; Wang, K.; Li, H.; Guan, X. Effect of LiAl-layered double hydroxides on hydration of calcium sulfoaluminate cement at low temperature. Constr. Build. Mater. 2019, 223, 910-917. [CrossRef]

106. Du, H.; Gao, H.J.; Dai Pang, S. Improvement in concrete resistance against water and chloride ingress by adding graphene nanoplatelet. Cem. Concr. Res. 2016, 83, 114-123. [CrossRef]

107. Du, H.; Dai Pang, S. Enhancement of barrier properties of cement mortar with graphene nanoplatelet. Cem. Concr. Res. 2015, 76, 10-19. [CrossRef]

108. Land, G.; Stephan, D. Controlling cement hydration with nanoparticles. Cem. Concr. Compos. 2015, 57, 64-67. [CrossRef]

109. Bräu, M.; Ma-Hock, L.; Hesse, C.; Nicoleau, L.; Strauss, V.; Treumann, S.; Wiench, K.; Landsiedel, R.; Wohlleben, W. Nanostructured calcium silicate hydrate seeds accelerate concrete hardening: A combined assessment of benefits and risks. Arch. Toxicol. 2012, 86, 1077-1087. [CrossRef]

110. Myrdal, R. Accelerating Admixtures for Concrete. State of the Art - (Technical Report SINTEF); SINTFE: Trondheim, Norway 2007.

111. Guan, X.; Li, H.; Luo, S.; Liu, X.; Zhang, J. Influence of LiAl-layered double hydroxides with 3D micro-nano structures on the properties of calcium sulphoaluminate cement clinker. Cem. Concr. Compos. 2016, 70, 15-23. [CrossRef]

112. Šiler, P.; Kolářová, I.; Másilko, J.; Novotnỳ, R.; Opravil, T. The Effect of Zinc on the Portland Cement Hydration. In Key Engineering Materials; Trans Tech Publications Ltd: Stafa-Zurich, Switzerland, 2018; Volume 761, pp. 131-134.

113. Asavapisit, S.; Fowler, G.; Cheeseman, C. Solution chemistry during cement hydration in the presence of metal hydroxide wastes. Cem. Concr. Res. 1997, 27, 1249-1260. [CrossRef]

114. Trezza, M.A. Hydration study of ordinary portland cement in the presence of zinc ions. Mater. Res. 2007, 10, 331-334. [CrossRef]

115. Li, F.; Duan, X. Applications of layered double hydroxides. In Layered Double Hydroxides; Springer-Verlag: Berlin, Heidelberg, Germany, 2006; pp. 193-223.

116. Martin, K.J.; Pinnavaia, T. Layered double hydroxides as supported anionic reagents. Halide-ion reactivity in zinc chromium hexahydroxide halide hydrates $[\mathrm{Zn} 2 \mathrm{Cr}(\mathrm{OH}) 6 \mathrm{X} . \mathrm{nH} 2 \mathrm{O}](\mathrm{X}=\mathrm{Cl}, \mathrm{I})$. J. Am. Chem. Soc. 1986, 108, 541-542. [CrossRef] [PubMed]

117. Tian, Y.; Dong, C.; Wang, G.; Cheng, X.; Li, X. Zn-Al-NO2 layered double hydroxide as a controlled-release corrosion inhibitor for steel reinforcements. Mater. Lett. 2019, 236, 517-520. [CrossRef] 
118. Poznyak, S.; Tedim, J.; Rodrigues, L.; Salak, A.; Zheludkevich, M.; Dick, L.; Ferreira, M. Novel inorganic host layered double hydroxides intercalated with guest organic inhibitors for anticorrosion applications. ACS Appl. Mater. Interfaces 2009, 1, 2353-2362. [CrossRef]

119. Cao, Y.; Dong, S.; Zheng, D.; Wang, J.; Zhang, X.; Du, R.; Song, G.; Lin, C. Multifunctional inhibition based on layered double hydroxides to comprehensively control corrosion of carbon steel in concrete. Corros. Sci. 2017, 126, 166-179. [CrossRef]

120. Carlino, S. The intercalation of carboxylic acids into layered double hydroxides: a critical evaluation and review of the different methods. Solid State Ionics 1997, 98, 73-84. [CrossRef]

121. DAvo, L. Anion-exchange in takovite: Applications to other hydroxide minerals. Bull. Miner. 1980, 103, 170-175.

122. Meyn, M.; Beneke, K.; Lagaly, G. Anion-exchange reactions of layered double hydroxides. Inorg. Chem. 1990, 29, 5201-5207. [CrossRef]

123. Costa, F.R.; Abdel-Goad, M.; Wagenknecht, U.; Heinrich, G. Nanocomposites based on polyethylene and $\mathrm{Mg}-\mathrm{Al}$ layered double hydroxide. I. Synthesis and characterization. Polymer 2005, 46, 4447-4453. [CrossRef]

124. Pöllmann, H.; Göske, J. Fixation of Chromate in Layered Double Hydroxides of the TCAH Type and Some Complex Application Mixtures. In Minerals as Advanced Materials II; Springer: Berlin, Heidelberg, 2011; pp. 103-114.

125. Hibino, T. Anion Selectivity of Layered Double Hydroxides: Effects of Crystallinity and Charge Density. Eur. J. Inorg. Chem. 2018, 2018, 722-730. [CrossRef]

126. Miyata, S. Anion-exchange properties of hydrotalcite-like compounds. Clays Clay Miner. 1983, 31, 305-311. [CrossRef]

127. Costa, D.G.; Rocha, A.B.; Souza, W.F.; Chiaro, S.S.X.; Leitão, A.A. Comparative Structural, thermodynamic and electronic analyses of $\mathrm{Zn}-\mathrm{Al}-\mathrm{A}^{n-}$ hydrotalcite-like compounds $\left(\mathrm{A}^{n-}=\mathrm{Cl}^{-}, \mathrm{F}^{-}, \mathrm{Br}^{-}, \mathrm{OH}^{-}, \mathrm{CO}_{3}^{2-}\right.$ or $\mathrm{NO}_{3}^{-}$): An ab initio study. Appl. Clay Sci. 2012, 56, 16-22. [CrossRef]

128. Miyata, S. The Syntheses of Hydrotalcite-Like Compounds and Their Structures and Physico-Chemical Properties-I: The Systems $\mathrm{Mg}^{2+}-\mathrm{Al}^{3+}-\mathrm{NO}_{3}^{-}, \mathrm{Mg}^{2+}-\mathrm{Al}^{3+}-\mathrm{Cl}^{-}, \mathrm{Mg}^{2+}-\mathrm{Al}^{3+}-\mathrm{ClO}_{4}^{-}, \mathrm{Ni}^{2+}-\mathrm{Al}^{3+}-\mathrm{Cl}^{-}$and $\mathrm{Zn}^{2+}-\mathrm{Al}^{3+}-\mathrm{Cl}^{-}$. Clays Clay Miner. 1975, 23, 369-375. [CrossRef]

129. Miyata, S.; Okada, A. Synthesis of hydrotalcite-like compounds and their physico-chemical properties-The systems Mg 2+-Al 3+-SO 4 2- and Mg 2+-Al 3+-CrO 4 2-. Clays Clay Miner. 1977, 25, 14-18. [CrossRef]

130. Duan, P.; Yan, C.; Zhou, W. Effects of calcined layered double hydroxides on carbonation of concrete containing fly ash. Constr. Build. Mater. 2018, 160, 725-732. [CrossRef]

131. Chen, Y.; Shui, Z.; Chen, W.; Chen, G. Chloride binding of synthetic Ca-Al-NO3 LDHs in hardened cement paste. Constr. Build. Mater. 2015, 93, 1051-1058. [CrossRef]

132. Shui, Z.; Yu, R.; Chen, Y.; Duan, P.; Ma, J.; Wang, X. Improvement of concrete carbonation resistance based on a structure modified Layered Double Hydroxides (LDHs): Experiments and mechanism analysis. Constr. Build. Mater. 2018, 176, 228-240. [CrossRef]

133. Tatematsu, H.; Sasaki, T. Repair materials system for chloride-induced corrosion of reinforcing bars. Cem. Concr. Compos. 2003, 25, 123-129. [CrossRef]

134. Zhonghe, S.; Juntao, M.; Wei, C.; Xiaoxing, C. Chloride binding capacity of cement paste containing layered double hydroxide (LDH). J. Test. Eval. 2012, 40, 796-800. [CrossRef]

135. Glasser, F.; Kindness, A.; Stronach, S. Stability and solubility relationships in AFm phases-Its solid solutions and their role in chloride binding. Cem. Concr. Res. 1999, 29, 861-866. [CrossRef]

136. Larsen, C. Chloride Binding in Concrete, Effect of Surrounding Environment and Concrete Composition. Ph.D. Thesis, The Norwegian University of Science and Technology, Trondheim, Norway, 1998; Volume 95, p. 337.

137. Hobbs, M.Y. Solubilities and Ion Exchange Properties of Solid Solutions between the Hydroxyl, Chlorine and Carbon Trioxide end Members of the Monocalcium Aluminate Hydrates. Ph.D. Thesis, University of Waterloo, Waterloo, ON, USA, 2001.

138. Suryavanshi, A.; Swamy, R.N. Stability of Friedel's salt in carbonated concrete structural elements. Cem. Concr. Res. 1996, 26, 729-741. [CrossRef]

139. Jones, M.; Macphee, D.E.; Chudek, J.; Hunter, G.; Lannegrand, R.; Talero, R.; Scrimgeour, S. Studies using 27Al MAS NMR of AFm and AFt phases and the formation of Friedel's salt. Cem. Concr. Res. 2003, 33, 177-182. [CrossRef] 
140. Struble, L. Synthesis and characterization of ettringite and related phases. In Proceedings of the 8th International Congress on yhe Chemistry of Cement, Rio de Janeiro, Brazil, 22-27 September 1986; Volume 1, pp. 449-482.

141. Hirao, H.; Yamada, K.; Takahashi, H.; Zibara, H. Chloride binding of cement estimated by binding isotherms of hydrates. J. Adv. Concr. Technol. 2005, 3, 77-84. [CrossRef]

142. Birnin-Yauri, U.; Glasser, F. Friedel's salt, $\mathrm{Ca}_{2} \mathrm{Al}(\mathrm{OH})_{6}(\mathrm{Cl}, \mathrm{OH}) \cdot 2 \mathrm{H}_{2} \mathrm{O}$ : Its solid solutions and their role in chloride binding. Cem. Concr. Res. 1998, 28, 1713-1723. [CrossRef]

143. Berke, N.S.; Rosenberg, A. Technical review of calcium nitrite corrosion inhibitor in concrete. Transp. Res. Rec. 1989,1211, 18-27.

144. Ann, K.Y.; Jung, H.; Kim, H.; Kim, S.; Moon, H.Y. Effect of calcium nitrite-based corrosion inhibitor in preventing corrosion of embedded steel in concrete. Cem. Concr. Res. 2006, 36, 530-535. [CrossRef]

145. Yang, Z.; Polder, R.; Mol, J. Modified hydrotalcites as chloride scavengers and inhibitor release agents for improved corrosion protection of reinforced concrete. Heron 2017, 62, 61.

146. Dry, C.; Corsaw, M. A time-release technique for corrosion prevention. Cem. Concr. Res. 1998, 28, $1133-1140$. [CrossRef]

147. Chen, L.J.; Chen, X.X.; Chen, W. Research on the Carbonation of Cement Paste Modified with Layered Double Hydroxides. In Applied Mechanics and Materials; Trans Tech Publications Ltd: Stafa-Zurich, Switzerland, 2012; Volume 174, pp. 706-710.

148. Cao, Y.; Zheng, D.; Dong, S.; Zhang, F.; Lin, J.; Wang, C.; Lin, C. A Composite corrosion inhibitor of MgAl layered double hydroxides co-intercalated with hydroxide and organic anions for carbon steel in simulated carbonated concrete pore solutions. J. Electrochem. Soc. 2019, 166, C3106-C3113. [CrossRef]

149. Shui, Z.H.; Ma, J.T.; Chen, W.; Gao, X. The effect of layered double hydroxides on the concrete resistance of chloride-ion penetration. In Key Engineering Materials; Trans Tech Publications Ltd: Stafa-Zurich, Switzerland, 2012; Volume 509, pp. 99-105.

150. Yang, Z.; Fischer, H.; Polder, R. Synthesis and characterization of modified hydrotalcites and their ion exchange characteristics in chloride-rich simulated concrete pore solution. Cem. Concr. Compos. 2014, 47, 87-93. [CrossRef]

151. Yang, Z.; Fischer, H.; Cerezo, J.; Mol, J.; Polder, R. Aminobenzoate modified MgAl hydrotalcites as a novel smart additive of reinforced concrete for anticorrosion applications. Constr. Build. Mater. 2013, 47, 1436-1443. [CrossRef]

152. Matschei, T.; Lothenbach, B.; Glasser, F.P. Thermodynamic properties of Portland cement hydrates in the system $\mathrm{CaO}-\mathrm{Al}_{2} \mathrm{O}_{3}-\mathrm{SiO}_{2}-\mathrm{CaSO}_{4}-\mathrm{CaCO}_{3}-\mathrm{H}_{2} \mathrm{O}$. Cem. Concr. Res. 2007, 37, 1379-1410. [CrossRef]

153. Xu, J.; Song, Y.; Zhao, Y.; Jiang, L.; Mei, Y.; Chen, P. Chloride removal and corrosion inhibitions of nitrate, nitrite-intercalated $\mathrm{MgAl}$ layered double hydroxides on steel in saturated calcium hydroxide solution. Appl. Clay Sci. 2018, 163, 129-136. [CrossRef]

154. Chung, C.W.; Jung, H.Y.; Kwon, J.H.; Jang, B.K.; Kim, J.H. Use of calcium aluminum-layered double hydroxide to control chloride ion penetration of cement-based materials. J. Struct. Integr. Maint. 2019, 4, 37-42. [CrossRef]

(C) 2020 by the authors. Licensee MDPI, Basel, Switzerland. This article is an open access article distributed under the terms and conditions of the Creative Commons Attribution (CC BY) license (http://creativecommons.org/licenses/by/4.0/). 